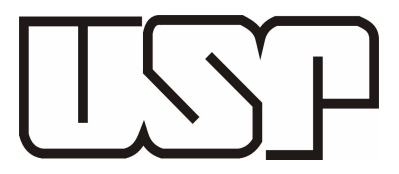

UNIVERSIDADE DE SÃO PAULO

FACULDADE DE FILOSOFIA, LETRAS E CIÊNCIAS HUMANAS

DEPARTAMENTO DE LETRAS CLÁSSICAS E VERNÁCULAS

PROGRAMA DE PÓS-GRADUAÇÃO EM FILOLOGIA E LÍNGUA PORTUGUESA

\author{
JULIANA CHAVES SOUZA
}

\title{
AQUISIÇÃO DOS TEMPOS VERBAIS DO PORTUGUÊS POR FALANTES DE LÍNGUAS TIMBIRA
}

Esta é uma versão corrigida, o exemplar original encontra-se disponível no CAPH (Centro de Apoio à Pesquisa Histórica) da FFLCH - USP.

SÃO PAULO

2011 


\section{JULIANA CHAVES SOUZA}

\section{AQUISIÇÃO DOS TEMPOS VERBAIS DO PORTUGUÊS POR FALANTES DE LÍNGUAS TIMBIRA}

Dissertação apresentada ao programa em Filologia e Língua Portuguesa, do Departamento de Letras Clássicas e Vernáculas da Faculdade de Filosofia, Letras e Ciências Humanas da Universidade de São Paulo, para obtenção do título de Mestre em Filologia e Língua Portuguesa.

Área de concentração: Filologia e Língua Portuguesa

Orientador: Profa. Dra. Rosane de Sá Amado

Esta é uma versão corrigida, o exemplar original encontra-se disponível no CAPH (Centro de Apoio à Pesquisa Histórica) da FFLCH-USP

De acordo:

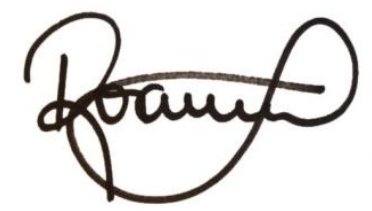

Prof $^{\circ}$ Dra. Rosane de Sá Amado

SÃO PAULO

2011 
Autorizo a reprodução e divulgação total ou parcial deste trabalho, por qualquer meio convencional ou eletrônico, para fins de estudo e pesquisa, desde que citada a fonte.

Catalogação na Publicação

Serviço de Biblioteca e Documentação

Faculdade de Filosofia, Letras e Ciências Humanas da Universidade de São Paulo

FICHA CATALOGRÁFICA

Souza, Juliana Chaves

Aquisição dos tempos verbais do português por

falantes de língua timbira / Juliana Chaves Souza ;

orientadora Rosane de Sá Amado. - São Paulo, 2011.

$85 \mathrm{f}$.

Dissertação (Mestrado) - Faculdade de Filosofia, Letras e Ciências Humanas da Universidade de São

Paulo. Departamento de Letras Clássicas e Vernáculas.

Área de concentração: Filologia e Língua Portuguesa.

1. Aquisição do português. 2. Línguas indígenas. 3.

Tempos verbais. 4. Morfologia. 5. Análise contrastiva. I.

Título. II. Amado, Rosane de Sá. 
NOME: SOUZA, Juliana Chaves

TÍTULO: Aquisição dos tempos verbais do português por falantes de línguas timbira

Dissertação apresentada ao programa em Filologia e Língua Portuguesa, do Departamento de Letras Clássicas e Vernáculas da Faculdade de Filosofia, Letras e Ciências Humanas da Universidade de São Paulo, para obtenção do título de Mestre em Filologia e Língua Portuguesa.

\section{BANCA EXAMINADORA:}

Prof. Dr. Rogério Vicente Ferreira (UFMS)

Prof. Dra. Maria Elizabeth Leuba Salum (Centro de Línguas - FFLCH - USP) 


\section{DEDICATÓRIA}

Ao povo timbira, fica aqui uma pequena contribuição no vasto campo de pesquisas linguísticas vitais para o fortalecimento de sua língua, cultura e sua alfabetização.

Ao meu marido Juliano, pelo incentivo e pela enorme paciência, que contribuíram para concretização dos meus objetivos como pesquisadora: a você, Juca, todo o теи amor!

Ao meu filho Murilo, que este seja um exemplo de empenho e perseverança! 


\section{AGRADECIMENTOS:}

À minha orientadora, professora Dra. Rosane de Sá Amado, por me ensinar os primeiros passos como pesquisadora ainda no segundo ano de graduação em Letras, por acreditar em meu potencial, por me estimular a continuar no caminho das pesquisas e por se mostrar, para além dos estudos, uma amiga atenciosa e compreensiva: muito obrigada!

Aos meus pais, Mario e Carmelita, que, mesmo sem muito compreender o que eu "tanto estudava", me incentivaram a persistir e nunca desistir dos meus sonhos.

Aos meus irmãos, Jaime e Tatiane, por sempre me mostrarem que há felicidade para além dos estudos...

Ao Centro de Línguas da FFLCH- USP, onde pude investigar e compreender melhor sobre a aquisição da língua portuguesa, durante a monitoria como professora de português para estrangeiros. Agradeço a todos os monitores os quais estiveram no período em que lecionei, bem como às secretárias, sempre dispostas a me ajudar e a tolerar meus desabafos...

À professora Dra. Maria Elizabeth Leuba Salum, pelo apoio durante a monitoria junto ao Centro de Línguas, por sua disposição constante e pelas valiosas sugestões no exame de qualificação.

Ao professor Rogério Vicente Ferreira, por aceitar o convite, se deslocar até São Paulo e pelos apontamentos importantes durante o meu exame de qualificação.

À Coordenação de Aperfeiçoamento de Pessoal de Nível Superior (CAPES) pelo auxílio financeiro durante os momentos finais de concretização desta pesquisa.

À Professora Márcia Santos Duarte de Oliveira (USP), por sua generosidade ao dedicar seu valioso tempo na a leitura deste estudo. 
Aos amigos que foram privados de minha total convivência, mas que, mesmo indiretamente, torcem pelo meu sucesso e felicidade: obrigada por existirem! 
"Espero uma vida melhor para o meu povo e que nosso futuro seja de sucesso paz e alegria. Que não nos esqueçamos do nosso modo de viver e que ele seja reconhecido no universo através de diversas contribuições físicas, entre outras. $E$ que os profissionais possam entender os dois mundos" 1

Pedro Jawirw Krahô (aluno timbira)

\footnotetext{
${ }^{1}$ Texto adaptado das redações timbiras
} 


\section{RESUMO}

Neste estudo procurou-se analisar sobre como se manifesta a aquisição dos tempos verbais do português por falantes de línguas timbira. Tal observação baseou-se em quarenta redações elaboradas por alunos indígenas matriculados no projeto: Uma escola Timbira, realizado pelas Secretarias de Educação do Maranhão e do Tocantins em conjunto com a FUNAI e com o Centro de Trabalho Indigenista (CTI) no ano de 2006.

Do corpus analisado, escolheu-se, como objeto de investigação, a aquisição dos tempos verbais da língua portuguesa, visto que as dificuldades de expressão quanto ao presente, passado e ao futuro ocorriam com grande frequência. Como bases teóricas, o Modelo de Análise de Erros (AE) juntamente com o Modelo de Análise Contrastiva (AC) contribuíram para a divisão e a classificação dos desvios de norma padrão da língua portuguesa e para o contraste entre a língua materna e a língua alvo, criando-se as hipóteses desse estudo.

Os resultados da pesquisa mostram que muitos desvios de norma padrão de L2 estão intimamente relacionados à transferência de parâmetros de L1 para L2, à substituição errônea de tempos verbais e ao uso de estratégias facilitadoras de referenciação à temporalidade.

PALAVRAS CHAVE: aquisição do português L2, morfologia, línguas indígenas, tempos verbais, análise contrastiva. 


\begin{abstract}
The aim of this study is to analyze how the acquisition of Portuguese verb tenses occurs for Timbira speakers. This observation was based on forty essays produced by indigenous students enrolled in the project Uma escola Timbira held by Departamento da Educação of the states of Maranhão and Tocantins in conjunction with FUNAI and Centro de Trabalho Indigenista (CTI) in 2006.

As a result of the analysis of the corpus, the acquisition of verb tenses in Portuguese was chosen as the object of this research, since the difficulties of expression for the present, past and future occur with high frequency. As a theoretical basis, the Model of Error Analysis (EA) together with the Model of Contrastive Analysis (CA) contributed to the division and classification of the deviations from the standard Portuguese norm and also to the contrast between the mother tongue and the target language, creating the hypotheses of this study.

The research results show that many deviations from the standard L2 are closely related to the transfer of parameters from L1 to L2, the erroneous substitution of tenses and the use of strategies to facilitate temporality reference.
\end{abstract}

KEY WORDS: acquisition of potuguese L2, morphology, indigenous languages, verb tenses, contrastive analysis. 


\section{LISTA DE QUADROS}

Quadro 1 - Inventário de fonemas das variantes timbira ..............................................22

Quadro 2 - Pronomes do pykobjê.......................................................................................26

Quadro 3 - Categorias de aspecto expressas por meio de auxiliares e outros operadores em

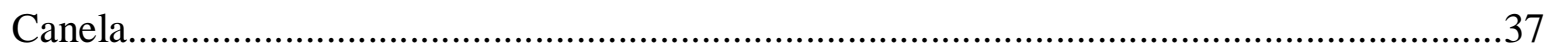

Quadro 4 - Classificação dos erros no tempo passado..................................................45

Quadro 5 - As estratégias usadas no tempo passado......................................................51

Quadro 6 - Advérbios temporais...................................................................................53

Quadro 7 - Os erros em relação ao tempo presente.........................................................58

Quadro 8 - Tempo futuro: as estratégias utilizadas........................................................63 


\section{SUMÁRIO}

INTRODUÇÃO 13

\section{CAPÍTULO 1: PARA CONHECIMENTO DO POVO E DA LÍNGUA TIMBIRA}

1. O tronco linguístico Macro-Jê...................................................................................18

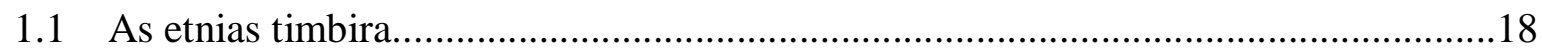

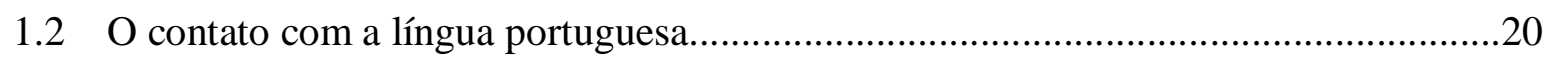

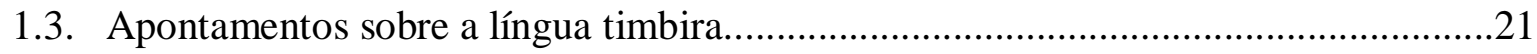

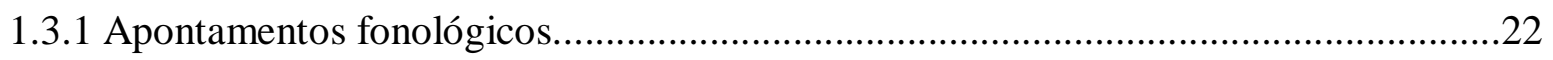

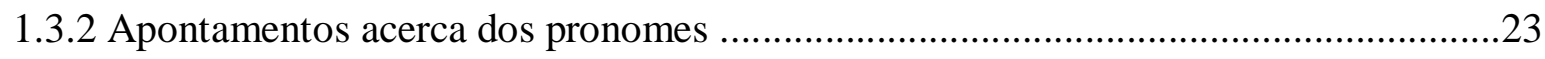

1.3.3 As formas verbais em timbira...............................................................................26

1.3.4 A expressão do tempo em timbira...........................................................................28

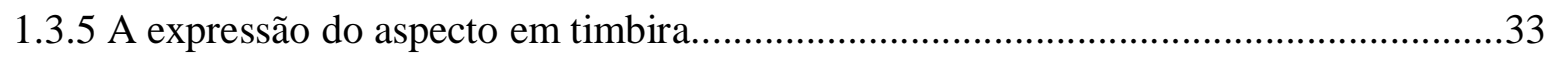

\section{CAPÍTULO 2: FUNDAMENTAÇÃO TEÓRICA}

2.1. O Modelo de Análise Contrastiva (AC) ...................................................................38

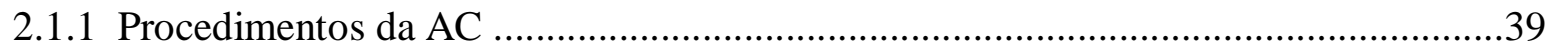

2.1.2 Trajetória e Críticas ao modelo..................................................................................39

2. 2 O modelo de Análise de Erros (AE) ……………..................................................40

2.2.1 O conceito de erro segundo a AE ....................................................................

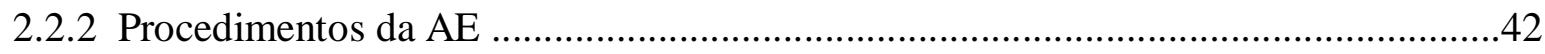

2.2.3 Trajetória e críticas ao modelo..............................................................................42

2.3 O modelo da interlíngua........................................................................................43

\section{CAPÍTULO 3: ANÁLISE DOS DADOS}

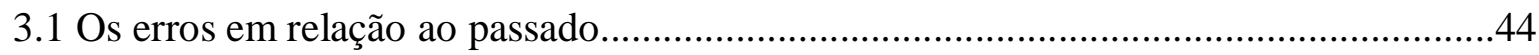

3.1.1 Classificação dos erros no tempo passado ...............................................................44

3.1.2 Uso do pretérito imperfeito no lugar do presente do indicativo..................................45

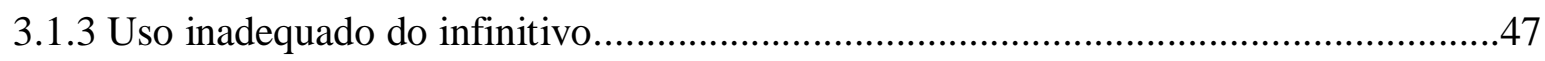

3.1.4 Uso do pretérito imperfeito pelo pretérito perfeito .....................................................48 


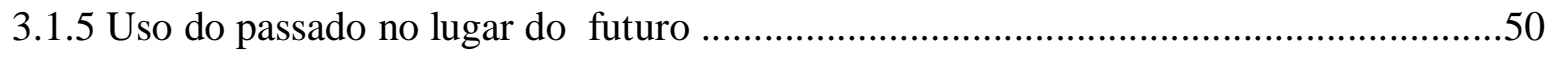

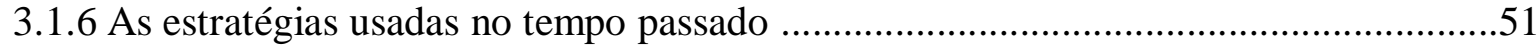

3.1.6.1 Uso de advérbios como auxiliares para marcação do tempo em início de tópico.....52

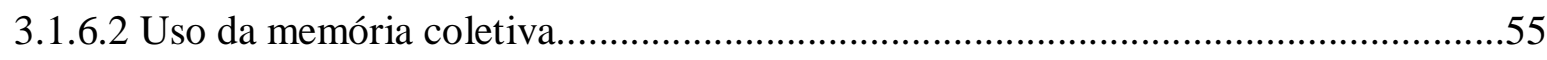

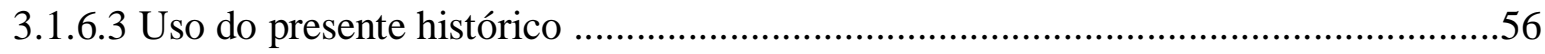

3.2 Os erros em relação ao presente ............................................................................58

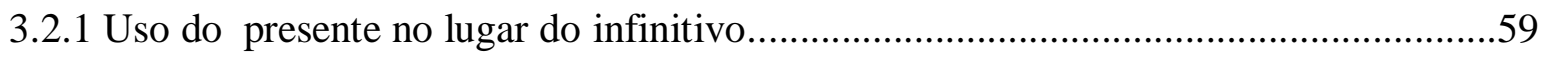

3.2.2 Uso do presente no lugar do gerúndio ...............................................................60

3.2.3 Uso do presente no lugar do pretérito.............................................................62

3.3 Tempo futuro: as estratégias utilizadas .......................................................62

3.3.1 Uso de marcadores verbais para iniciar um tópico ..............................................63

3.3.2 Uso da perífrase verbal: ir + infinitivo ...........................................................64

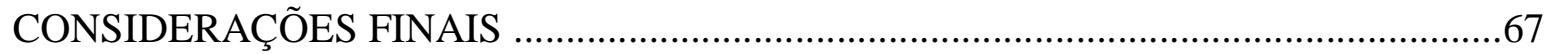

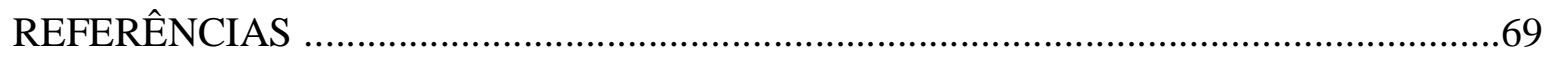

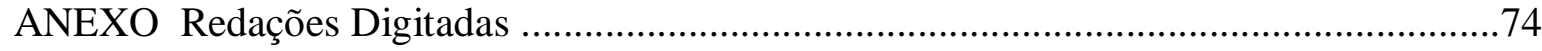

APÊNDICE Divisão e classificação dos erros das redações..........................................82 


\section{INTRODUÇÃO}

O presente estudo pretende abarcar as dificuldades de aquisição da língua portuguesa por falantes de línguas indígenas, mais especificamente dificuldades acerca da morfologia verbal do português por falantes de línguas timbira, pertencentes à família Jê que por sua vez está atrelada ao tronco linguístico Macro-Jê. Essa preocupação nasceu após a observação sobre da produção escrita do português por estudantes das oito etnias que compõem o complexo timbira, a saber: Krinkati, Gavião-pykobjê, Krenjê, Canelaramkokamekrá, Canela-apãniekrá, Krahô, Apinajé, Gavião-parkatejê.

Os timbira mantêm viva a tradição oral e o contato com a tradição letrada em língua portuguesa ainda é recente, sendo a escrita pouco utilizada entre os indígenas no cotidiano das aldeias. Ladeira (2001, p. 311) refere-se a este fato ao dizer que, entre os timbira, a comunicação se processa pela oralidade, dispensando internamente a necessidade do uso da escrita. Entretanto, o crescente interesse na aquisição do português por esses povos tem gerado estudos linguísticos acerca do português como segunda língua (L2) aprendido por eles. Ferreira Neto, em seu trabalho com a língua Waiãpi, delata a precariedade de formação de pesquisadores indígenas e a necessidade de estudos linguísticos do português L2

Em qualquer dessas discussões, a língua portuguesa é o ponto de partida. Tratando-a como língua estrangeira é possível tomá-la em seus aspectos puramente formais, abstraindo seu contexto de uso, de forma tal que a manipulação de suas unidades estruturais possa ocorrer sem que se corra o risco de proceder às impropriedades pragmáticas comuns no manejo das línguas indígenas por pesquisadores linguistas que as tem como língua estrangeira. (1997, p.2)

Dessa maneira, os estudos sobre morfologia, tais como sobre o tempo e o aspecto verbal do português escrito, podem revelar mais sobre situação de contato entre primeira língua (L1) e segunda língua (L2) e mostrar as interferências que a língua materna pode causar no aprendizado da língua alvo.

Embora a fluência em língua portuguesa dos falantes de línguas timbira possa ser considerada de nível intermediário, devido ao seu uso na comunicação com os não indígenas e, por ser aprendida ainda na infância, na idade de cinco a seis anos, quando as crianças começam a frequentar as escolas sediadas dentro das aldeias, os falantes 
apresentaram grandes dificuldades na elaboração dos textos que compõem a base do corpus desta pesquisa. Tais textos estão em forma de redações dos tipos descritivo, narrativo e expositivo-argumentativo, produzidos por alunos indígenas, participantes do X Módulo do Ensino Fundamental da Escola timbira, realizado pelas Secretarias de Educação do Maranhão e do Tocantins em conjunto com a FUNAI e com o Centro de Trabalho Indigenista (CTI) no ano de 2006. Nessas redações é possível detectar, além dos aspectos linguísticos, muito da tradição e da cultura indígena. Do corpus inicial de 209 redações, foram selecionadas 40 , do tipo dissertativo,que eram as que versavam sobre a preservação das tradições indígenas no passado, na atualidade e no futuro com o intuito de se trabalhar com problemas relacionados aos tempos presente, passado e futuro da língua portuguesa. Segue o tema abaixo:

Conte como eram as tradições do seu povo no passado, como elas estão sendo preservadas atualmente e como você pensa que elas estarão no futuro.

Do total das redações selecionadas e que desenvolviam o tema proposto, houve o destaque das orações que se distanciavam da norma padrão da língua portuguesa em relação às desinências modo-temporais e, posteriormente, a reunião dos erros comuns em uma classificação conforme o tipo e a frequiência do erro. Assim, nas tabelas que apresentaremos no capítulo que compete a analise dos dados, a percentagem de desvios que destacamos se refere às quarenta redações que compõem o corpus deste estudo. Ainda, reiteramos que pudemos constatar mais de um erro em uma redação como também ocorreu da mesma apresentar um único desvio repetidas vezes. ${ }^{2}$

O contraste entre os sistemas linguísticos do português e do timbira é de suma importância na comprovação das hipóteses de desvios na escrita do português pelos indígenas, pois sua língua materna muito difere da língua alvo. Na estrutura de L1, há a inserção de diferentes partículas que fazem a distinção entre passado e não passado, estabelecem o futuro e delimitam o aspecto. Ainda nas variantes timbira, há o sistema ergativo e a distinção de pronomes que acompanham o tempo passado e não passado. De acordo com Alves (2009,p.15), o canela-apãniekrá utiliza, para a expressão do tempo e de

\footnotetext{
${ }^{2}$ Para melhor esclarecimento sobre a metodologia utilizada ver apêndice 1.
} 
categorias aspectuais, partículas no início da oração; além disso, uma série de palavras funcionais pode ocorrer no final da oração para expressar categorias de aspecto e modalidade.

Em contraposição, sabe-se que no português o radical apresenta a significação permanente do verbo, cabendo às desinências ou sufixos flexionais a indicação das noções gramaticais. Em adição, os verbos portugueses classificam-se morficamente em três conjugações, de acordo com a vogal temática que apresentam. As discrepâncias percebidas entre as duas línguas comprovam um distanciamento significativo que parece afetar a aquisição de L2, o que confirmaria as afirmações de Lado:

os estudantes em contato com uma língua estrangeira encontrarão estruturas relativamente fáceis e outras extremamente difíceis na aquisição. Os elementos que são similares com a sua língua nativa serão fáceis de serem aprendidos e os diferentes serão difíceis. $(1957, \text { p. } 2)^{3}$

Da mesma forma, por se considerar as produções escritas dos estudantes timbira, pretendemos nos apoiar no modelo de Análise de Erros (AE) para a localização e classificação dos desvios de norma padrão do português relacionados às flexões verbais. Este modelo parece ser significativo, pois, trata o erro como algo útil e necessário na aquisição de L2 ; ainda, suas causas podem se basear não somente na interferência de L1, como se proclama na Análise Contrastiva, mas também nas características de L2 ou até nas próprias estratégias de ensino.

Assim, a linguística contrastiva de Lado (1957) juntamente com o modelo de investigação de Análise de Erros de Corder (1967) servirão de apoio teórico no desenvolvimento desta pesquisa.

As justificativas para o conhecimento pleno da escrita do português brasileiro entre os povos timbira são sustentadas, principalmente, pelos próprios indígenas que, frequentemente, optam pela alfabetização em L2 em detrimento da alfabetização em sua própria língua. Ladeira (1981) confirma tal afirmação e menciona a língua portuguesa como ferramenta importante de integração do índio na vida nacional.

\footnotetext{
${ }^{3}$ We assume that the students who comes in contact with a foreign language will find some features of quite easy and others extremely difficult. Those elements that are similar to his native language will be easy for him and those elements that are different will be difficult (LADO, 1957, p 2) (tradução nossa)
} 
Em geral os índios não pedem a alfabetização na própria língua, mas insistem na necessidade da alfabetização em português...Quando os índios exigem a alfabetização no português é justamente para fazer frente à situação do contato. Os índios sabem muito bem que para "dominar" o português precisam dominá-lo em sua totalidade: "a língua do cristão é uma língua que se fala e se escreve” (LADEIRA 1981, p.3)

Além disso, a constituição de 1988 garante às comunidades indígenas o direito do ensino regular em língua portuguesa e assegura a utilização de sua língua materna no processo de aprendizagem. Desta forma, espera-se que o ensino do português possa ser diferenciado entre os indígenas, devendo ser tratado como segunda língua (L2), neste caso, as questões relacionadas à estrutura de (L1) são passíveis de fortalecer o processo de aprendizado.

Segundo Baccili (2008), muitos professores indígenas não estão conscientes de que lecionar uma L2/LE é diferente de ensinar a língua materna e de que ensinar português não é repetir padrões previamente selecionados, mas sim dar base de conhecimento ao aluno para que ele possa criar novas sentenças. Além disso, o ensino do português entre as comunidades indígenas deve abarcar as dificuldades advindas da prática da oralidade que interferem significativamente na escrita e na subjetividade desta expressão.

De acordo com Luke e Freebody (1997), a leitura e a escrita são práticas sociais que fazem usos de textos escritos como meio de construção e reconstrução de frases, mensagens e significados. Em outras palavras, a construção do pensamento crítico na prática da leitura e da escrita revela as percepções do indivíduo acerca de sua sociedade. Desta forma, é preciso respeitar e levar em consideração a maneira com que cada indivíduo visualiza o mundo e a tradição oral indígena pode ser considerada mais uma ferramenta na construção do pensamento crítico, pois a trajetória de transmissão da cultura através da oralidade, deve ser explorada na construção de um leitor/escritor ativo que, como defendem os autores, cria significados com base em sua própria história e perspectiva.

Ladeira (1999) também discorre sobre a necessidade de um ensino diferenciado nas aldeias, que englobe o conhecimento tradicional e, ao mesmo tempo, trate das questões culturais e étnicas dos grupos indígenas 
Respeitar as características culturais e ter a possibilidade de uma escola diferenciada, como garante a constituição, não é simplesmente fazer uma adaptação empobrecida das escolas da cidade, é pensar novos rumos, é descobrir uma nova cara para estas escolas, dando a ela a sua condição de indígena, diferenciada. (1999, p. 12)

Assim, a presente pesquisa foca-se na verificação do uso dos tempos verbais do português (L2) nas redações produzidas por estudantes timbira. Tal emprego será analisado conforme a referência aos tempos passado, presente e futuro a fim de se detectar os erros relacionados ao mau uso das desinências modo-temporais da língua portuguesa em sua modalidade padrão. Deste modo, analisaremos as causas dos erros bem como as interferências de L1 no aprendizado de L2 através do contraste entre a língua timbira e o português. Desta forma, esta pesquisa se pauta no sentido de ser uma contribuição para o que garante a constituição brasileira: o de assegurar o ensino do português, língua requerida frequentemente na comunidade indígena, mas principalmente, assegurar ainda que na aprendizagem de L2 estejam presentes considerações sobre a língua materna indígena. 


\section{CAPÍTULO 1}

\section{Para conhecimento do povo e da língua timbira}

\section{0 tronco linguístico Macro-Jê}

Os povos que falam línguas do tronco linguístico Macro-Jê distribuem-se geograficamente em regiões de campos e cerrados localizados no sul do Maranhão e do Pará, nos estados de Goiás e Mato Grosso e em campos meridionais dos estados de São Paulo, Paraná, Santa Catarina e Rio Grande do Sul.

Este tronco ${ }^{4}$ possui uma descrição ainda hipotética, sendo a família Jê a maior evidência de compartilhamento de características comuns entre as línguas abarcadas. Desta forma, além da correspondência regular entre os sons da língua e da similaridade histórica de um certo número de palavras, as línguas das famílias propostas como filiadas ao tronco Macro-Jê têm, em comum, características gramaticais.

Rodrigues (1999) reuniu trabalhos deste tronco linguístico e mostrou estruturas recorrentes nas línguas Macro-Jê em relação à fonologia, à sintaxe e à morfologia. Segundo o pesquisador, as línguas Macro-Jê são aglutinantes e levemente sintéticas. Além disso, as classes de palavras são mais definidas por estratégias sintáticas do que por afixação. Em relação ao verbo, o autor também discorre que, em muitas línguas do tronco, não se faz a concordância verbal, mas algumas marcam o sujeito em concordância com a frase nominal na sentença.

\subsection{As etnias timbira}

O complexo timbira é formado por etnias que se caracterizam, por suas características físicas, linguísticas e culturais, como pertencentes à família Jê, que por sua

\footnotetext{
${ }^{4}$ Representa a classificação das línguas de tipo genético que consiste em reunir numa só classe as línguas que tenham tido origem comum numa língua anterior. Esta língua anterior é reconstruída pelos linguistas de maneira que seus vocábulos possam se fazer derivar, por meio de leis fonéticas os vocábulos atuais que constituem a referida classe. Deste modo, o tronco linguístico reúne as línguas classificadas como famílias; as famílias oriundas de uma língua ainda mais remota são agrupadas em um bloco e os blocos que apresentam certas afinidades são, por sua vez, colocados em um mesmo filo.
} 
vez está relacionada ao tronco Macro-Jê. Este povo é dividido em orientais e ocidentais, sendo os orientais os que estão a leste do rio Tocantins, e os ocidentais os que estão a oeste deste mesmo rio:

Timbira orientais (leste do rio Tocantins)

Timbira de Araparytiua

Kukóekamekra e Kr̃eyé de Bacabal

$\mathrm{Kr}^{\sim}$ eyé de Cajuapára

Kre/púmkateye

Pukópye e $\mathrm{Kr}^{\sim}$ ikateye

Gaviões

Apányekra (Canellas de Porquinhos)

Ramkókamekra (Canellas do Ponto)

Krahó

Timbira ocidentais (oeste do rio Tocantins)

Apinayé (NIMUENDAJÚ, 2001 p.1)

Alguns grupos habitam uma área relativamente plana e coberta pelo cerrado, outros ficam na transição entre o cerrado e a floresta amazônica. Geralmente em referência ao povo timbira, alguns apelidos são importantes em sua descrição, são eles: Canela: (Ramkokamekrá, Apanyekrá e Kenkateyê) e Gavião (Krinkati, Gavião Pykopjê e Gaviões do Oeste). Os parentes mais próximos dessas etnias são os Kayapó do norte, os Suyá e os Panará. O número de indígenas denominados timbira se aproxima de oito mil indivíduos de acordo com os dados da FUNASA e FUNAI. ${ }^{5}$

Há aproximadamente duzentos anos, esses grupos eram, predominantemente, compostos de caçadores e coletores, seminômades, que durante determinados períodos do ano andavam pelo cerrado maranhense. Atualmente, o povo timbira está em contato pacífico com a sociedade nacional desde o século XIX e mantêm seus hábitos, costumes, rituais e língua materna preservados, apesar dos impactos sofridos pelo largo período de contato.

O primeiro trabalho de referência aos timbira é de autoria de Nimuendaju (1946) que elaborou um estudo antropológico de descrição desses povos. Vem deste autor a

5 Conforme Ávila (2004) disponível em http://www.trabalhoindigenista.org.br/papers.asp. Acesso em 05.11.2010. 
nomenclatura timbira que faz referências às características culturais que eles compartilham, a saber: o corte de cabelo, as pinturas corporais, as cerimônias religiosas, a fabricação de artesanato e sobretudo a celebração da corrida de toras.

Nimuendaju contribuiu ainda, para o agrupamento das línguas timbira no tronco Macro-Jê, que inicialmente contava com quinze etnias, mas algumas já se encontravam extintas no período dessa classificação; além disso, apresentou a configuração das tribos, a vida social, as cerimônias, as crenças e religiões deste povo.

Por fim, podemos afirmar que os timbira procuram, há muito, manter seus costumes, rituais e culturas, sendo a manifestação de suas tradições uma contribuição significante para o fortalecimento de sua unidade cultural.

\section{$1.2 O$ contato com a língua portuguesa}

O ensino do português escrito entre os povos timbira tem início no século passado. Segundo Ladeira (1999), há registro de que Frei Rafael de Taggia em 1841, já mantinha, entre os krahô, uma escola para que eles aprendessem a língua de contato com os nãoindígenas, devido a necessidades da agricultura. Desta forma, a língua portuguesa passou um grande período sendo transmitida por missionários, até que a FUNAI começou a fornecer assistência na implementação de escolas. Ladeira também afirma que os timbira, nos dias atuais, continuam funcionalmente analfabetos, pois a leitura não se tornou uma experiência significativa que levasse ao enriquecimento da experiência da vida. Como agravante, a organização da escola e o acompanhamento pedagógico da aldeia pouco considera em sua prática a organização social indígena e seus hábitos culturais.

Atualmente, a situação das escolas nas aldeias timbira é bastante diversificada: há escolas acompanhadas pelas secretarias estaduais de educação, outras que recebem o apoio dos municípios e da FUNAI e há escolas ou ações experimentais apoiadas pelo Centro de Trabalho Indigenista.

Além disso, há a realização de módulos de reforço ao ensino fundamental, projeto realizado pelas Secretarias de Educação do Maranhão e do Tocantins em conjunto com a FUNAI e com o Centro de Trabalho Indigenista (CTI). A última edição do Projeto Uma 
Escola Timbira deu-se no ano de 2006 com a realização do $10^{\circ}$ módulo do projeto, que teve a duração de três semanas no intuito de reforçar o aprendizado mantido nas escolas das aldeias.

Os participantes do $10^{\circ}$ Módulo da Escola Timbira foram jovens entre vinte e trinta anos. Na oportunidade, a Profa. Dra. Rosane de Sá Amado desenvolveu e lecionou o curso de língua portuguesa conforme as necessidades indígenas percebidas por ela em relação ao ensino do português. Houve a apresentação de textos e músicas cujos temas aproximavam os indígenas da cultura dos não indígenas; em paralelo, foram discutidos os estereótipos que estes últimos faziam daqueles. Ao final de cada aula, cujo enfoque era sempre linguístico, os alunos compuseram diferentes redações sobre o tema abordado, parte dessas redações se tornou o corpus para a realização da presente dissertação.

Ao longo deste estudo, pudemos supor que as dificuldades na escrita do português estão intimamente ligadas à problemática de aquisição de L2, principalmente em conseqüência da interlíngua dos estudantes, pois estes recorrem a diversas construções errôneas na tentativa de adquirir a língua alvo. Essas constatações podem estar relacionadas, também, à implementação de uma escola adequada que não desvalorize o modo de vida, os ritos e cerimônias realizadas ao longo do ano e, principalmente, que considere a língua indígena no processo de aprendizagem.

\subsection{Apontamentos sobre a língua Timbira}

Os trabalhos linguísticos que contribuem para o conhecimento da estrutura da língua das diferentes etnias que compõem o complexo timbira são: os de Alves (1999, 2002, 2004) sobre os apãniekrá, os de Amado (1999, 2004, 2005) referente aos pykobjê, os de Araújo (1989) e de Ferreira (2003) sobre os parkatejê, e o de Souza (1997) acerca dos krahô. As demais etnias são mais descritas em trabalhos antropológicos e socioculturais que não contribuem de forma significativa em descrições linguísticas.

Neste tópico, procuraremos discorrer, primeiramente, acerca da fonologia da língua timbira para o conhecimento dos segmentos, da sílaba e do acento, com o intuito de um melhor entendimento dos morfemas e da estrutura da língua timbira. Posteriormente, tornam-se necessários os apontamentos sobre estrutura morfológica, objeto de estudo desta 
pesquisa, a fim de compreendermos como se manifesta a concepção de tempo em timbira e em seguida como L1 pode interferir na aquisição de L2.

\subsubsection{Apontamentos Fonológicos}

Em relação à língua falada pelas etnias, os trabalhos mais relevantes de caráter fonológico são os de Alves (1999) e de Sá (1999). Ainda, há controvérsias se as línguas do grupo seriam próximas ou apontariam para variantes de uma única língua; de qualquer modo, Rodrigues (1986) afirma que o complexo linguístico em questão compreende atualmente as variantes apãniekra, ramkokamekrá, krĩnkati, krahô, parkatejê e pykobjê. A língua apinajé apresenta diferenças lexicais, fonológicas e morfossintáticas em sua estrutura e está mais próximo da língua kaiapó, embora os falantes dessa língua compartilhem características culturais comuns aos timbira e, por esta razão, se encontrem inseridos nos projetos de educação que congregam esses últimos.

O trabalho de Alves (2004) descreve o seguinte inventário de fonemas:

Quadro 1 - Inventário de fonemas das variantes timbira (Alves, 2004, p. 18)

\begin{tabular}{|c|c|c|c|}
\hline Apinajé & Parkatejê & Apãniekrá/Ramkok/Krahô & Krinkati/Pykobjê \\
\hline $\mathrm{pt} \mathrm{t} \int \mathrm{k} ?$ & $\mathrm{ptt} \mathrm{t} \mathrm{k} ?$ & $\mathrm{pt} \mathrm{t} \int \mathrm{k} ?$ & $\mathrm{pt} \mathrm{t} \int \mathrm{k} \mathrm{k}^{\mathrm{h}} ?$ \\
\hline $\mathrm{m} n \mathrm{n} \quad \mathrm{g}$ & $\mathrm{m} \mathrm{n}$ & $\mathrm{mn} \quad \mathrm{n} \quad$ & $\mathrm{m} \mathrm{n}$ \\
\hline$w r j$ & $\mathrm{w} \mathrm{rjh}$ & $\mathrm{w} \mathrm{r} \mathrm{j} \mathrm{h}$ & $\mathrm{wrjh}$ \\
\hline$\dot{i} \tilde{1} \dot{\mathrm{i}} \tilde{\mathrm{t}} \mathrm{u} \tilde{\mathrm{u}}$ & i $\tilde{1}$ u u u u $\tilde{u}$ & $\dot{i} \tilde{1} \dot{\mathrm{i}} \tilde{\mathrm{t}} \mathrm{u} \tilde{\mathrm{u}}$ & $\dot{i} \dot{\mathrm{i}} \mathrm{u}$ \\
\hline e $\partial \mathrm{o}$ & $\tilde{\mathrm{e}} \gamma \tilde{\mathrm{o}}$ & e $\partial \mathrm{o}$ & e $\tilde{\mathrm{e}} \partial \tilde{\partial} \mathrm{o} \tilde{\mathrm{o}}$ \\
\hline$\varepsilon \tilde{\varepsilon} 3 \tilde{3} っ \tilde{\jmath}$ & $\varepsilon \Lambda 0$ & $\varepsilon \tilde{\varepsilon} 3 \supset \tilde{\jmath}$ & \\
\hline a ã & $\mathrm{a} \tilde{a}$ & a $\tilde{a}$ & $\mathrm{a}$ \\
\hline
\end{tabular}


Nessa comparação, percebemos que o inventário de segmentos consonantais é praticamente o mesmo, salvo a série de nasais, a oclusiva velar aspirada / $\mathrm{k}^{\mathrm{h}} /$ que só ocorre no pykobjê, as nasais, palatal e velar / $\mathrm{n} / \mathrm{e} / \mathrm{\eta} /-$, que não ocorrem no parkatejê, no krinkati e no pykobjê, e a fricativa glotal / h /que não ocorre no apinajé. Deste modo, está nas vogais o maior número de divergências entre as línguas do grupo, embora a variação vocálica seja previsível.

Em relação à sílaba, Alves (1999) e Sá (1999) apontam para o padrão máximo $\mathrm{C}(\mathrm{C}) \mathrm{V}(\mathrm{C})$ podendo apresentar ataques complexos e privilegiando-se o padrão CVC .

$\mathrm{O}$ acento em timbira tende a recair na última sílaba da raiz. Uma observação interessante é a de Sá (1999) que afirma que na análise de empréstimos do português notase que, além de ocorrer um apagamento da última vogal da sílaba canônica CV em vocábulos com mais de uma sílaba, em casos de proparoxítonas, todas as sílabas posteriores são apagadas até o vocábulo tornar-se oxítono e pesado. Exemplos:

\begin{tabular}{|c|c|}
\hline $\begin{array}{l}\text { português } \\
\text { 'sa.ja }\end{array}$ & $\begin{array}{l}\text { pykobyê } \\
\text { tfai }\end{array}$ \\
\hline 'xe.di & rit \\
\hline sa.'rõ.pu & 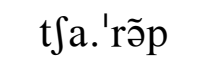 \\
\hline bi.si.'kle.ta & be.se.'kret \\
\hline 'o.ni.bus & $o^{1} n$ \\
\hline 'sa.ba.du & t $\int a p$ \\
\hline
\end{tabular}

(SÁ, 1999, p.27)

Outra característica marcante na fala dos timbira, mais especificamente na língua dos índios gavião, é o que se encontra no IPA (International Phonetic Alphabet) com o nome de efeito "breathy voice", tal distinção fornece à fala dos índios uma marca de "sotaque" que se assemelha a um "murmúrio" De acordo com Sá (1999), ainda que seja um diacrítico cultural dos pykobjê, ele pode ser considerado uma variante social de idade dentro da própria comunidade, visto que somente os indígenas mais velhos o produzem. 


\subsubsection{Apontamentos acerca dos pronomes}

$\mathrm{Na}$ apresentação da morfologia timbira, faz-se necessário destacar a classe de palavras pronomes e sua oposição entre as formas livres (independentes) e presas, ou prefixos (dependentes). O primeiro ocorre quando sujeito de verbos transitivos e intransitivos e nunca como objetos, já o segundo difere por sua característica básica de estar permanentemente ligados a outros itens na sentença e ocorrer como sujeito de verbos no tempo passado simples, como objeto de verbos transitivos e como objeto de posposições. Vejamos alguns exemplos:

krahô (SOUZA, 1997, p.20)

$(01)$

$$
\begin{array}{cr}
\boldsymbol{k} \boldsymbol{e} & \text { kré } \\
\text { '3' } & \text { 'cantar' } \\
\text { 'ele(s) } & \text { canta(m)' }
\end{array}
$$

$$
\begin{array}{cc}
\text { in- } \quad k r e ́ \\
\text { 'eles' } \quad \text { 'cantar' } \\
\text { 'ele cantou' }
\end{array}
$$

$$
\begin{array}{ccc}
m e^{6} & \text { in- } & \text { krér } \\
\mathrm{pl} & 3- & \text { cantar } \\
& \multicolumn{2}{c}{\text { 'eles cantaram' }}
\end{array}
$$

Como podemos perceber, para sujeitos de verbos ativos no tempo passado, exemplos (02) e (03), são usados os pronomes dependentes. Além disso, com verbos

\footnotetext{
${ }^{6}$ De acordo com Souza (1997) somente os pronomes considerados de forma presa recebem o marcador de plural 'mé', pois os de formas livres comportariam em si a ideia de plural, com exceção da primeira pessoa do singular 'wa'. Para maiores esclarecimentos ver Souza (1997) p.23
} 
transitivos, os pronomes dependentes obrigatoriamente ligam-se à posposição te, que marca o caso ergativo.

apãniekra (ALVES, 2004, p.84)

(04)

\begin{tabular}{|c|c|c|c|}
\hline$k u-$ & $t \varepsilon$ & $=m \tilde{\varepsilon}$ & $a-$ \\
\hline 3 & ERG & $=\mathrm{PL}$ & 2 \\
\hline
\end{tabular}

pykobjê (AMADO, 2009, p.10)

(05)

$\begin{array}{cccc}\text { ej- } & \text { te } & \text { rop } & \text { popo } \\ 1 & \text { ERG } & \text { 'onça' } & \text { 'ver' } \\ & \text { 'eu vi uma onça' } & \end{array}$

Já como sujeitos de verbos intransitivos, os pronomes dependentes ligam-se diretamente aos verbos:

pykobjê (AMADO, 2004, p.10)

(06)

$$
\begin{array}{cr}
\text { ej- } & \text { pemter } \\
1 & \text { 'sonhar' } \\
\text { 'eu sonhei' }
\end{array}
$$

$$
\begin{array}{lr}
\text { a:- } & \text { pemter } \\
2 & \text { 'sonhar' } \\
\text { 'você sonhou' }
\end{array}
$$


Uma vez usados os pronomes formas livres como sujeito dos verbos, a interpretação temporal de passado perfeito é dissipada, nessas circunstâncias, temos a referência ao tempo presente:

krahô (SOUZA, 1997, p.22)

(08)

$$
\begin{array}{rr}
w a & p a ̂ m \\
1 & \text { 'cair' } \\
\multicolumn{2}{c}{\text { 'eu caio' }}
\end{array}
$$

(09)

$$
\begin{array}{ccc}
\boldsymbol{w a} & \text { apu } & m \tilde{o} \\
1 & \text { CONT } & \text { 'ir' }
\end{array}
$$

Desta forma, podemos relacionar os pronomes pessoais e sua interpretação temporal conforme o quadro:

Quadro 02 - Pronomes do pykobjê (Amado, 2004, p. 74)

\begin{tabular}{|c|c|c|c|c|}
\hline & \multicolumn{2}{|c|}{$\begin{array}{c}\text { Sujeito de verbos ativos com o tempo não } \\
\text { passado }\end{array}$} & \multicolumn{2}{c|}{$\begin{array}{c}\text { Sujeito de verbos ativos com } \\
\text { tempo passado }\end{array}$} \\
\hline & Futuro & Presente & Transitivo & Intransitivo \\
\hline $1 \mathrm{~s}$ & wa & wa & ej - & ej - \\
\hline $2 \mathrm{~s}$ & ka & ka & a: - & e?/ø \\
\hline $3 \mathrm{~s}$ & ki & $\varnothing$ & ko - & mẽ ej - \\
\hline 1 incl & wa mẽ & wa mẽ & mẽ ej - & mẽ ej - \\
\hline 1 excl & ko mẽ & ko mẽ & mẽ ej - & mẽ a: - \\
\hline $2 p l$ & ka mẽ & ka mẽ & mẽ a: - & mẽ ?-/ mẽ ø \\
\hline $3 p l$ & ki mẽ & mẽ & mẽ ko - & \\
\hline
\end{tabular}


No quadro, podemos perceber que a distinção maior acontece na terceira pessoa que, quando sujeito de verbos ativos no singular, pode variar entre as formas ki para o futuro e $\varnothing$ no presente, além de ki mẽ e mẽ para a representação de plural no futuro e no presente respectivamente. Ainda, semelhante variação pode ocorrer com os pronomes de terceira pessoa quando sujeito de verbos ativos no tempo passado.

Além dos pronomes pessoais de formas livre e presa o timbira também apresenta os pronomes pessoais enfáticos, reflexivos e demonstrativos, que não serão tratados aqui ${ }^{7}$.

\subsubsection{As formas verbais}

Ao analisarmos os verbos em timbira, uma primeira observação a ser feita é a variação em suas formas, relatada na maioria dos trabalhos; esta variação está relacionada aos verbos ativos que expressam o tempo passado simples, podendo ser transitivos ou intransitivos (Ferreira, 2003; Alves, 2004; Amado, 2006). Assim, de acordo com uma regra morfofonológica, o final do radical da maioria dos verbos é modificado podendo ser acrescidos os fonemas $(\mathrm{m}, \mathrm{n}, \mathrm{p}, \mathrm{r}, \mathrm{t}, \mathrm{j} \mathrm{k})^{8}$; a forma resultante é a forma derivada do verbo não finito.

pykobjê (AMADO, 2006, p.2)

$$
\begin{array}{ccc}
\text { ej - te } & k^{h} \text { row } & t f \partial r \\
1 \text { ERG } & \text { 'flecha' } & \begin{array}{c}
\text { 'guardar' } \\
\text { 'eu guardei a flecha' }
\end{array} \\
\text { wa } & k^{h} \text { row } & t f \boldsymbol{t} \\
1 & \text { 'flecha' } & \text { 'guardar' } \\
\text { 'eu estou guardando a flecha' }
\end{array}
$$

\footnotetext{
7 Para um maior conhecimento a respeito dos pronomes na língua timbira, sugere-se a leitura de Amado (2004), Souza (1997) e Alves (2004).

${ }^{8}$ Conforme Alves (2004) para a variante Apaniekrá. Amado (2006) considera os fonemas m, n ou r para o Pykobjê.
} 


$$
\begin{array}{ccr}
\text { ej-te } & \text { rop } & \text { korən } \\
1 \text { ERG } & \text { 'onça' } & \text { 'matar' }
\end{array}
$$

$\begin{array}{ccccc}\text { awkaPte } & \text { wa } & \text { ha } & \text { rop } & \text { kora } \\ \text { 'amanha' } & 1 & \text { fut } & \text { 'onça' } & \text { 'matar' } \\ \text { 'amanhã eu vou matar a onça' } & \end{array}$

\begin{tabular}{rcccc} 
ej-te & $k u \quad$ to & ej- & kom \\
1 erg & 'agua' & 'causa' & 1 & 'beber' \\
\multicolumn{4}{c}{ 'eu bebi água' }
\end{tabular}

$\begin{array}{cccccc}\text { wa } & \text { ha } & k u & \text { to } & \text { ej- } & \text { ko } \\ 1 & \text { 'fut' } & \text { 'agua' } & \text { 'causa' } & 1 & \text { 'beber' } \\ & & & \text { 'eu vou beber água' } & & \end{array}$

Nos exemplos citados, percebemos que os verbos guardar, matar e beber no tempo passado apresentam uma forma diferenciada chamada de longa por AMADO (2006) com a presença dos segmentos r, m, n; nos demais tempos essas consoantes sofrem uma apócope e a forma é denominada breve. Além disso, para alguns autores, tais manifestações podem ser apresentadas como formas estendidas e não-estendidas (Ferreira, 2003), ou formas finitas e não-finitas (Alves, 2004).

\subsubsection{A expressão do tempo em timbira}

O tempo na língua timbira parece fazer uma divisão passado e não passado, sendo este último subdividido entre presente e futuro. A primeira distinção, passado e não passado, é feita pelo uso dos pronomes pessoais e pela presença da posposição \{te $\}$ nas orações transitivas; já o futuro é diferenciado do presente pelo uso da partícula \{ha $\}$ - que é mais bem caracterizada como uma partícula modalizadora - bem como por partículas aspectuais. Vejamos: 
pykobjê (AMADO, 2004, p. 126)

(14)

$$
\begin{array}{cccc}
w a & \boldsymbol{h a} & k u & j a k j i \\
1 & \text { fut } & \text { 'água' } & \text { 'buscar' } \\
& \text { 'eu vou buscar água' }
\end{array}
$$

$$
\begin{array}{rcc}
w a & \mathrm{ku} & j a k j i \\
1 & \text { 'agua' } & \text { 'buscar' }
\end{array}
$$

'eu estou buscando água'

$$
\begin{array}{cccc}
e j- & \boldsymbol{t} \boldsymbol{\varepsilon} & k u & j a k j i n \\
1 & \text { ERG } & \text { 'água' } & \text { 'buscar' } \\
& \text { 'eu busquei água' } &
\end{array}
$$

Nos dados acima, notamos o uso da partícula $\{$ ha $\}$ para diferir tempo futuro (ex. 14) de tempo presente (ex. 15). Vemos ainda que o pronome pessoal é distintivo para marcar tempos não passado de tempo passado, no caso, de $\{$ wa $\}$ para $\{$ ej- $\}$ e, como a oração (16) possui verbo transitivo, aparece a marca de ergatividade representada pela partícula $\{$ te $\}$, que será tratada adiante. É importante salientar que o tempo passado simples não ocorre marcado nos predicados nominais e nas orações com verbos intransitivos não ativos.

A categoria temporal presente é considerada não marcada em timbira, conforme os exemplos 17 e 18:

apãniekra (ALVES, 2009, p.2)

(17)

$$
\begin{array}{lccc}
\text { kahãj } & / & i P^{2} & p K \\
\text { 'mulher' } & \text { PRES } & 3 & \text { 'carregar' } \\
\multicolumn{3}{c}{\text { 'a mulher o carrega' }}
\end{array}
$$




kupr $\quad / \quad$ ape
'menina' PRES 'comer'
'a menina come'

Já para o futuro, como visto anteriormente no exemplo 14, consideramos a partícula \{ha\} como indicadora desta marca temporal, detectada nas variantes pykobjê, apãniekra e krahô. Entretanto, segundo Alves (2004) esta partícula também aparece em orações com o uso modal irrealis e por este motivo podemos afirmar que ela também caracteriza uma diferença modal:

apãniekrá (ALVES, 2004, p.67)

\begin{tabular}{cccccccccc}
$k e$ & $a w-$ & $p a$ & $n \tilde{a}$ & $m \tilde{a}$ & $k e$ & $\boldsymbol{h a}$ & $i P_{-}$ & $t$ toj & $\eta j k r \varepsilon$ \\
3 & DTR & 'ouvir' & SUB & DS & 3 & IRR & $3-$ & 'forte' & 'cantar' \\
& & \multicolumn{4}{c}{ 'ele ouviria se ele cantasse' } & & &
\end{tabular}

ke ha ku- $\quad t \int_{3} \quad n \tilde{a}$ mã ke ha ramã rop kura 3 IRR 3 'morder' SUB DS 3 IRR ASP 'cachorro' 'matar' 'ele o mataria se o cachorro o mordesse'

Outra evidência a favor da diferença modal (realis vs. irrealis) da partícula $\{$ ha\} é o uso do tempo presente, auxiliado pela partícula $\{\mathrm{ma}\}$, na menção o futuro imediato:

apãniekra (ALVES, 2004, p. 67)

(21)

$\begin{array}{ccc}w a & \boldsymbol{m a} & m \tilde{\boldsymbol{s}} \\ 1 & \text { DIR } & \text { 'ir' }\end{array}$

$\begin{array}{ccccc}k u & \text { pa- } & \text { pjakrut } & \text { ma } & t \tilde{\varepsilon} \\ 1 \text { inclu } & \text { linclu } & \text { dois } & \text { DIR } & \text { 'viajar' }\end{array}$


'nós dois vamos viajar'

De qualquer maneira, a partícula $\{$ ha $\}$ também é detectada em segunda posição na manifestação de futuro próximo e com o uso de auxiliares verbais de tempo + aspecto:

pykobjê (AMADO, 2004, p. 39)

$\begin{array}{cccc}\text { Wa } & \text { ha } & \text { kopot } & \text { kora } \\ 1 & \text { FUT } & \text { 'guariba' 'matar' } \\ & \text { 'eu vou matar o guariba' }\end{array}$

krahô (SOUZA, 1997, p. 39)

\begin{tabular}{cccrc} 
wa & ha & ma & ra & ten \\
1 & aux & aux & adv 'vir' \\
\multicolumn{4}{c}{ 'eu já irei embora' }
\end{tabular}

\begin{tabular}{|c|c|c|c|c|c|}
\hline Ape & $n a$ & ke & $h a$ & apa & $p e$ \\
\hline 'amanhã' & posp & 3 & aux & aux & trabalhar \\
\hline
\end{tabular}

Com relação à referência de tempo passado em timbira, este não é marcado nos predicados nominais e nas sentenças com verbos intransitivos não-ativos. No entanto, conforme visto no tópico 1.3.2, é importante a relação sintática dos pronomes pessoais considerados de forma presa (Amado, 2009; Souza, 1997; Ferreira, 2003) e sua manifestação na referência ao tempo passado no aspecto perfectivo. Vejamos:

krahô (SOUZA, 1997, p. 21, 25)

(26)

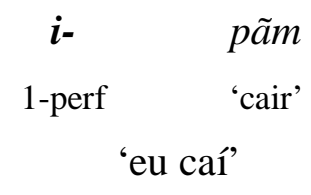


(27)

$$
\begin{array}{cr}
\boldsymbol{w a} & p \tilde{a m} \\
1 & \text { 'cair' } \\
& \text { 'eu caio' }
\end{array}
$$

$$
\begin{array}{cccccc}
\boldsymbol{k u} & \text { aypen pupu pÿt kuna kâm } \\
1 / 2 & \text { recip 'ver' 'sol' 'todo' ‘em' } \\
& \text { 'nós nos vemos todos os dias' }
\end{array}
$$

$$
\begin{array}{llll}
\text { pa- } & \text { té aypen ko pupun } \\
1 / 2 & \text { perf recip 'agua' 'ver' } \\
\text { 'nós nos vimos na água' }
\end{array}
$$

Ainda com relação ao passado, há uma oposição entre passado vivido/ passado distante (ou passado não vivido) conforme Alves (2004). O primeiro refere-se a uma situação que se realizou antes do momento da fala e que ainda é recente na perspectiva de quem fala; já o segundo descreve situações que ocorreram em um passado considerado de longa data; neste último caso se insere a partícula $\{$ pe $\}$ para descrever tais situações.

apãniekra (ALVES, 2009, p. 5)

(30) Passado vivido

$$
\begin{array}{cr}
\boldsymbol{h} \text { - } & \text { әpon } \\
3 & \text { 'comer' } \\
\text { 'ele comeu' }
\end{array}
$$

(31) Passado distante

$\begin{array}{ccc}\boldsymbol{P e} & \varnothing & \text { apə } \\ \mathrm{PD} & 3- & \text { 'comer' } \\ \text { ‘ele comeu' } & \text { (quando era pequeno) }\end{array}$


(32) Passado vivido

rop $\quad t \varepsilon \quad i-\quad t$ t $a r$

Cachorro $\quad$ ERG $\quad 1 \quad$ 'morder'

'o cachorro me mordeu'(há pouco tempo)

(33) Passado distante

$\begin{array}{cccr}P e & \text { rop } & i- & \text { t far } \\ \text { PD } & \text { cachorro } & 1 & \text { 'morder' }\end{array}$

'o cachorro me mordeu' (quando eu era pequena)

Em relação à morfossintaxe, o timbira apresenta um alinhamento ergativoabsolutivo condicionado pela expressão do passado recente, denominado ergatividade cindida por Alves (2004). Nestes casos, o sujeito dos verbos transitivos, quando em orações que expressam tempo passado simples, vem marcado obrigatoriamente pelo marcador do caso ergativo \{te $\}$. Segundo Alves, a evidência para tal consideração é que esse marcador é sempre usado posposto a um sintagma nominal (SN) que está na função agente (A), e nunca posposto a um SN em função sujeito(S) ou objeto $(\mathrm{O})$.

apãniekra (ALVES, 2009, p. 6)

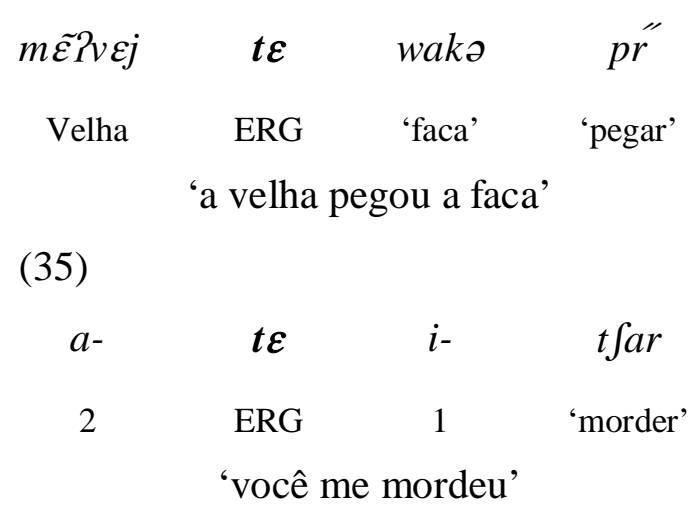




\subsubsection{A expressão do aspecto em timbira}

A categoria aspectual em timbira é representada pelo uso de partículas, bem como pela presença de auxiliares e outros marcadores verbais como numerais e expressões; desta forma, não há morfemas afixados ao verbo na manifestação dessa categoria.

O aspecto progressivo ou continuativo em timbira é representado pela partícula $\{$ apu $\}$ :

apãniekra (ALVES, 2009, p. 6)

Wa apu apo

1 PROG 'comer'

'eu estou comendo'

parkatejê (FERREIRA, 2003, p.120)

(37)

\begin{tabular}{cr}
\multicolumn{1}{c}{ apu } & awrt \\
CONT & 'chover' \\
'está chovendo'
\end{tabular}

O aspecto de ação recentemente completada é expresso pela partícula $\{$ kurmõ $\}$ :

parkatejê (FERREIRA, 2003, p. 121)

(38)

\begin{tabular}{|c|c|c|c|}
\hline 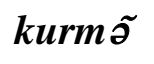 & $k a$ & $a-$ & kator \\
\hline Rcompl & 'tu' & $2-$ & 'chegar' -pas \\
\hline \multicolumn{4}{|c|}{ 'tu acabaste de chegar' } \\
\hline \multicolumn{4}{|l|}{ (39) } \\
\hline$i-$ & t3 & kurm $\tilde{\boldsymbol{\theta}}$ & tokrE \\
\hline 1 & ERG & Rcomple & 'cavar' \\
\hline
\end{tabular}


'eu acabei de cavar'

Para indicar uma ação que se repete, temos a partícula \{apiri\}, que representa aspecto iterativo:

parkatejê (FERREIRA, 2003, p. 123)

(40)

apiri aikati.
Iter dia $\quad$ Loc $\quad$ Iter $\quad$ Rel 'fezes' verb+pass
'Novamente amanheceu. Novamente (ela a lua) viu
as fezes (dele, do sol)'

As partículas \{aykó\} e \{ykó\} denotam o aspecto imperfectivo:

krahô (SOUZA, 1997, p.37)

(41)

$\begin{array}{cccc}\text { Kéti } & \text { aykó } & \text { kra } & \text { yahe } \\ \text { Tio } & \text { IMPER } & \text { paca } & \text { 'caçar } \\ & \text { 'Meu tio caçava paca' }\end{array}$

(42)

pe
wa ykó minti yaher
enf 1 IMPER 'jacaré' 'caçar'
'Também eu caçava jacaré'

Além das partículas, a categoria aspectual em timbira também pode ser representada por auxiliares verbais como to $=\mathbf{m} \tilde{\jmath}$ e $\mathbf{t} \boldsymbol{\jmath}=\mathbf{t} \tilde{\varepsilon}$. Nestes casos a partícula to aparece com verbos de movimento indicando progressividade:

apãniekra (ALVES, 2009, p. 8) 


$\begin{array}{llcc}i \text { i? } & \text {-ykrə } & \text { to } & =\boldsymbol{m} \tilde{\boldsymbol{q}} \\ 3 & \text { 'secar' } & \text { Posp } & \text { 'ir' } \\ & \text { 'Ele está secando' } & \end{array}$

$\begin{array}{cccccc}\text { wa } & \text { t } \text { tikar } & j^{-} & \text {ak or } & \text { to } & \boldsymbol{t} \tilde{\boldsymbol{\varepsilon}} \\ 1 & \text { 'cigarro' } & \text { PR } & \begin{array}{c}\text { 'soltar } \\ \text { fumaça' }\end{array} & \text { Posp } & \text { ir }\end{array}$

'eu saí fumando um cigarro'9

Ainda, conforme Alves (2009) uma série de 'palavras funcionais' pode ocorrer no final da oração. São operadores que expressam categorias de aspecto indicadas lexicalmente pelo uso de certos verbos ('acabar', 'parar', 'viver', 'começar', 'ser muitos' etc.), flexionados ou não, seguindo o verbo principal (em sua forma não-finita). Deste modo, para os apãniekra há a menção dos seguintes aspectos:

apãniekra (ALVES, 2009, p. 9)

(45) Aspecto terminativo

ka ари a- j- зpen to $h$ amre

2 Prg 2 PR 'trabalhar' Posp 3- 'acabar'

'você está acabando do trabalhar'

(46) Aspecto continuativo

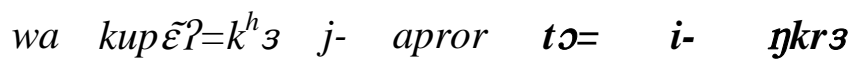

1 'pano' Pr 'levar' posp 1 'viver'

'eu continuo comprando pano'

${ }^{9}$ Construção ambígua, outras possíveis interpretações: eu fui andando e fumando ou eu estava fumando. 
(47) Aspecto Ingressivo

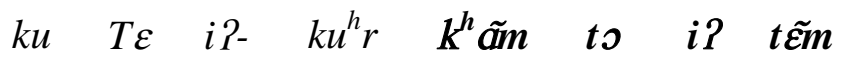

3 ERG 3- 'comer' Posp Posp 3- ir 'ele começou a comer carne'

(48) Aspecto Iterativo

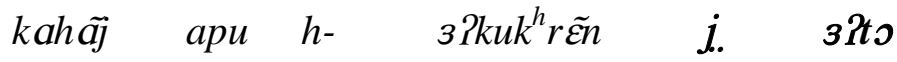

'mulher' PROG $3 \quad$ 'correr' $\quad$ PR 'ser

'competindo' muitos'

'a mulher está correndo muitas vezes'

Além disto, outros operadores podem ocorrer em posição final para marcar o aspecto como: os numerais, codificando o aspecto continuativo; a partícula par(tu) (tudo, completamente); ou a expressão î-k hã kura (matar, acabar completamente)

De acordo com Alves (2009), para a expressão do aspecto em Canela-Apãniekrá, têm-se o seguinte quadro:

Quadro 3 - Categorias de aspecto expressas por meio de auxiliares e outros operadores em Canela (Alves 2009, p.11)

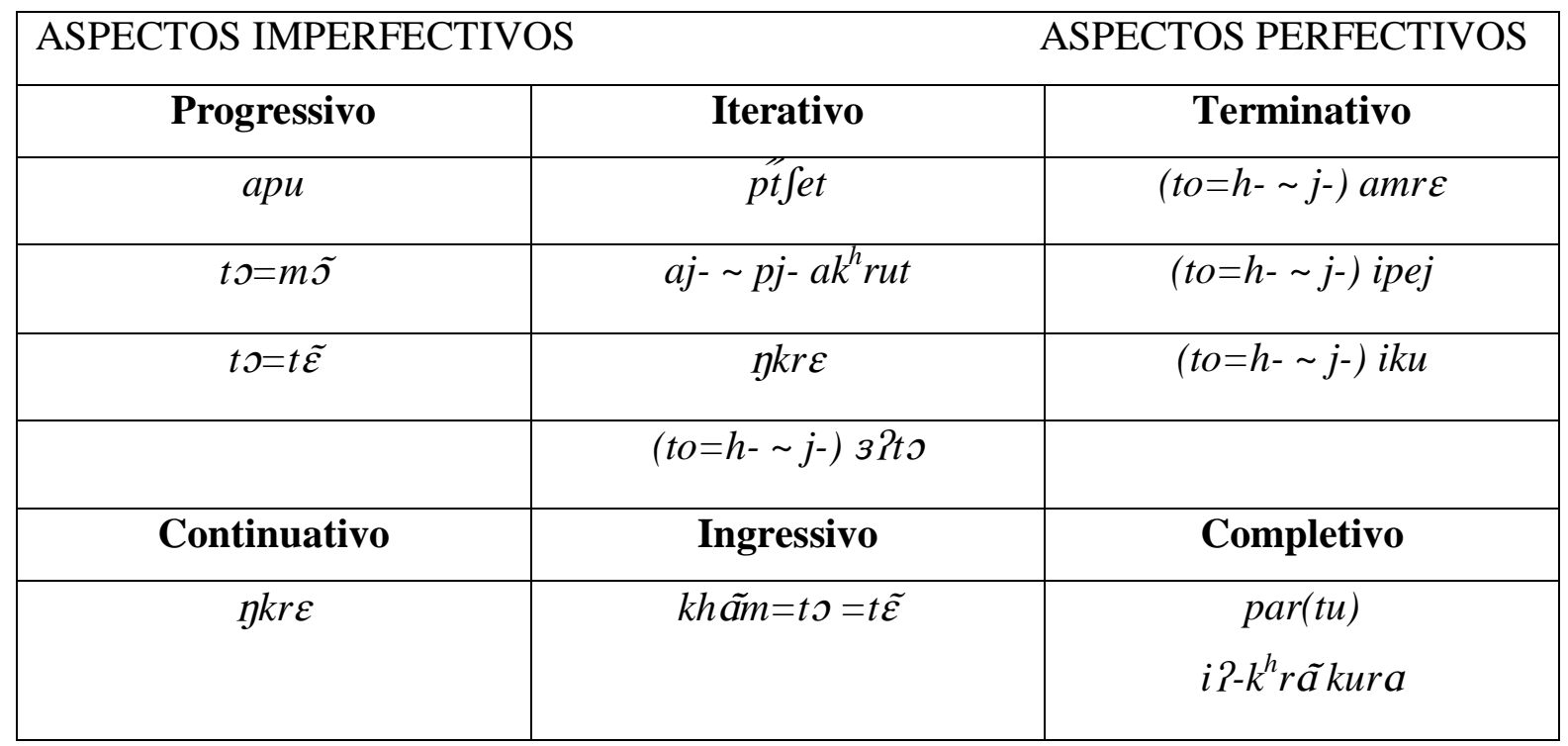


Por fim, nota-se que, nos trabalhos linguísticos referidos, a categoria aspectual em timbira ainda é um objeto de estudo a ser explorado mais profundamente, pois não há referências de uma pesquisa completa sobre este assunto e muitas partículas parecem ser ambíguas, como a partícula to. Entretanto, as observações realizadas neste capítulo são importantes no sentido de contribuir para o estudo da aquisição do tempo e do aspecto em L2, mostrando as diferenças no sistema linguístico do timbira em contraste com o do português. 


\section{CAPÍTULO 2}

\section{Fundamentação Teórica}

Neste capítulo discorreremos sobre os conceitos de Análise Contrastiva (AC), Análise de Erros (AE) e Interlíngua (IL) de forma a enfatizar os dois primeiros modelos que servirão de base à análise dos dados.

Consideramos o modelo da AE importante para a identificação e classificação dos erros de norma padrão em relação às flexões verbais; da mesma forma a AC nos auxiliará na comprovação das hipóteses iniciais de interferência de L1 na aprendizagem de L2. Desta maneira acatamos a proposta de Filipovic (1985), o qual apresenta a necessidade do trabalho em paralelo com $\mathrm{AC}$ e a $\mathrm{AE}$ e recomenda o estudo em conjunto, pois considera que uma pesquisa propriamente contrastiva poderia ser incompleta e que a Análise de Erros pode oferecer informações importantes para a aquisição de línguas.

\subsection{O modelo de Análise Contrastiva (AC)}

O modelo de análise contrastiva proposto por Fries (1945) e Lado (1957) fundamenta-se no conceito de que estudantes em contato com uma língua estrangeira encontrarão elementos linguísticos fáceis de serem aprendidos e outros extremamente difíceis. Os elementos considerados fáceis serão os que se assemelham com a L1 e os difíceis serão os elementos diferentes de L1. Essa hipótese, proposta por Lado, deriva da teoria do behaviorismo, que defende que a aquisição de línguas é uma formação de hábitos que se aprendem por meio de estímulo-resposta, comportamento este que estaria intimamente relacionando com estruturalismo norte-americano de L. Bloomfield.

De acordo com o modelo, na aprendizagem de L2 há a distância interlinguística que media a língua nativa e a língua alvo; quanto maior for essa distância, maior será a dificuldade de aprendizagem e a possibilidade de interferências fonéticas, morfológicas, sintáticas ou lexicais originadas da L1. Além disso, os autores postulam que as diferenças e similaridades entre duas línguas poderão apontar as áreas de dificuldades e servir para o professor prever os problemas que os estudantes enfrentarão no processo de aprendizagem, 
usando os resultados para a correção e preparação de materiais didáticos e para as técnicas de instrução.

Os conceitos de transferência e de erros foram as bases da AC, sendo o primeiro um fenômeno em que um traço linguístico da estrutura de L1 ocorre na aprendizagem de L2; já o segundo caracteriza-se como um desvio de norma da língua alvo, originado pela interferência da L1.

\subsubsection{Procedimentos da AC}

Segundo Gargallo (1993), as afirmações de Lado e Fries convergem de maneira explícita para a ideia de que os estudantes tendem a transferir as estruturas e o vocabulário de sua língua materna quando aprendem uma segunda língua ou uma língua estrangeira, tanto em sua fase de produção como na recepção de uma determinada língua. A autora apresenta os procedimentos estruturais necessários para a comparação de duas línguas de acordo com a o modelo de Análise Contrastiva, conforme abaixo:
a) descrição estrutural de L1 e L2
b) cotejo das descrições
c) elaboração de uma lista preliminar de estruturas não equivalentes
d) reagrupamento das estruturas não equivalentes estabelecendo uma hierarquia de dificuldade
e) previsão e descrição das dificuldades
f) preparação dos materiais didáticos.

De acordo com esses procedimentos, a meta final da AC é construir uma gramática que estabeleça uma hierarquia de correspondências dos diferentes níveis, com o propósito de apontar as áreas de dificuldades na aprendizagem e as possibilidades de interferência.

\subsubsection{Trajetória e críticas ao modelo}

O modelo de AC passou por duas versões ao longo de sua trajetória: sua versão forte postula a possibilidade de prever, mediante comparação sistemática entre L1 e L2, as 
áreas de dificuldades que os aprendizes enfrentarão no processo de aprendizagem; já a sua versão fraca resume-se a diagnosticar e explicar as descobertas e resultados obtidos. As primeiras etapas do modelo de AC estavam baseadas em teorias estruturalistas; no entanto, o modelo foi sendo adaptado por outras teorias como o gerativismo e a psicolinguística, passando por reformulações que buscavam ampliar as possibilidades do estudo e mostrar que não somente as dificuldades, mas as similaridades devem ser consideradas no processo de aprendizagem.

Uma das maiores críticas ao modelo deu-se por se considerar a AC fragmentária e esta não abranger a explicação de todos os erros cometidos na aprendizagem de L2, visto que nem todos eram causados pela interferência linguística. Outra crítica apontava para o fato da previsão dos erros pelos aprendizes, os quais nem sempre realizavam o que era previsto. Desta maneira, segundo Gargallo, em quase todos os projetos empíricos realizados notou-se a necessidade de trabalhar simultaneamente com a AC com o modelo da Análise de Erros. Além do mais, alguns autores como Filipovic (1985), já citado anteriormente, consideram que uma pesquisa propriamente contrastiva poderia ser incompleta e fragmentária de forma que a Análise de Erros pode oferecer informações importantes e revelar mais sobre o processo de aquisição.

Por fim, as investigações da Análise Contrastiva foram um constituinte importante da linguística aplicada, pois elevou o papel do aluno para protagonista em sala de aula, e não mais o professor, como era pensado até o momento. Como consequência, surgiu uma preocupação séria e científica de facilitação do processo de aprendizagem que gerou o surgimento das gramáticas contrastivas, além de ser um apoio científico para as intuições do professor.

\subsection{O Modelo de Análise de Erros (AE)}

Após o declínio da Análise Contrastiva na década de sessenta, surge o modelo de Análise de Erros proposto por Corder (1967), cuja inspiração era advinda da sintaxe gerativa de Chomsky e que culminou em uma reformulação tanto da teoria de aprendizagem como o tratamento do erro sob uma perspectiva mais tolerante. 
A AE se baseia em um estudo sistemático dos erros cometidos pelos aprendizes de uma segunda língua durante o processo de aquisição, objetivando investigar as causas dos mesmos e chegar a explicações mais abrangentes do que a proposta da Análise Contrastiva.

De acordo com Gargallo (1993) o modelo da AE dispõe das seguintes vantagens:

- é uma contribuição significativa para a linguística aplicada;

- eleva o status do erro, pois passa a ser visto como signo mais positivo do que o processo em que ele ocorre;

- indica aos professores quais as áreas oferecerão mais dificuldade para os alunos, e com isto o docente poderá estar consciente do ponto do processo em que o aluno se encontra e que estratégias o aluno pode estar utilizando;

-estabelece uma hierarquia de dificuldades, iluminando as prioridades do ensino; -produz materiais didáticos e revisa os que já estão formulados; -constrói um teste importante para determinados objetivos e níveis.

\subsubsection{O Conceito de erro segundo a $\mathrm{AE}$}

Segundo Corder (1967) é necessária uma diferenciação entre os conceitos de erro, falta e lapso na aprendizagem de uma L2: o erro é um desvio linguístico sistemático enquanto a falta decorre de uma ação inconsciente e eventual; já um lapso significa um desvio baseado em fatores extralinguísticos como falta de concentração, cansaço, falta de memória entre outros. Sendo assim, o erro pode ser positivo quando se é considerado algo inevitável e necessário no processo de aprendizagem, ou pode ser considerado negativo quando se trata de uma inadequação das técnicas de aprendizagem e das estratégias usadas pelos estudantes.

Compreendemos assim que, para a $\mathrm{AE}$ o erro é algo útil e necessário, pois é uma característica sistemática que reflete a competência transitória em um certo momento no processo de aquisição; ainda, suas causas podem se basear não somente na interferência de L1, mas também nas características de L2 ou até nas próprias estratégias de ensino. 


\subsubsection{Procedimentos da AE}

Conforme Gargallo (1993), a AE dispõe da seguinte metodologia:
a) determinação dos objetivos;
b) descrição do perfil do informante;
c) seleção do tipo de prova ou teste;
d) elaboração da prova ou teste;
e) realização da prova ou teste;
f) identificação dos erros;
g) classificação dos erros de acordo com uma taxonomia previamente estabelecida;
h) determinação estatística da ocorrência dos erros;
i) descrição dos erros em relação às causas;
j) identificação das áreas de dificuldades de acordo com uma hierarquia;
k) programação de técnicas para o tratamento dos erros em sala de aula;
1) determinação do grau de irritabilidade do ouvinte;
m) determinação das implicações didáticas no ensino.

\subsubsection{Trajetória e Críticas ao modelo}

A Análise de Erros surgiu da necessidade de reformulação da AC, onde o erro era analisado como um hábito persistente da língua materna na aquisição de L2. O novo modelo nascia de forma a destacar que os erros dos aprendizes refletiam algumas estratégias universais através do conceito de performance advindo da sintaxe gerativa. Dessa maneira, os erros que não eram anteriormente explicados pela AC agora ganham uma nova perspectiva de forma a demonstrar que eles são parte do fenômeno caracterizado pelas diferentes etapas pelas quais atravessa um estudante em seu processo de aprendizagem antes de alcançar a competência desejada

O conceito de erro passou a ser reformulado e isto gerou implicações em sua correção, através da adoção de posturas mais tolerantes, e na proposta pedagógica de ensino, esta última marcada pelo enfoque comunicativo. 
Corder (1967) também introduz o conceito de sistema transitório, que representa o sistema linguístico de um estudante de L2, no qual estão inseridas as características da língua nativa, da língua alvo e outras propriamente idiossincráticas. Este conceito foi uma das bases para a teoria de Interlíngua que mais tarde veio a sobrepor o modelo da $\mathrm{AE}$.

As maiores críticas à Análise de Erros fundamentaram-se na confusão entre a descrição e a explicação dos erros, na falta de precisão na descrição das categorias e na fragmentação dos resultados obtidos. Ao final da década de 1960, nascia o conceito de Interlíngua que veio a apontar novos rumos para a teoria da linguística aplicada e abranger novos conceitos para aquisição de L2, não abarcados pela AE.

\subsection{O modelo de Interlíngua}

A Interlíngua é a área que examina um sistema linguístico transitório, resultado de situações distintas do contato entre línguas. Tal sistema envolve muitos processos como a transferência positiva ou negativa (advindas da análise contrastiva), a disposição do falante em querer aprender a língua alvo e a interação entre as línguas.

Selinker (1972) introduz o termo interlíngua como referência à linguagem autônoma de um estudante de L2. De acordo com o autor, o 'output' do estudante é imprescindível na criação de hipóteses para o modelo, pois a medida entre a língua nativa L1 e a língua alvo L2 diminui gradativamente, sendo este um processo criativo que atravessa sucessivas etapas marcadas por novas estruturas e vocabulário que o aluno adquire.

Como característica específica, a Interlíngua apresenta os termos fossilização e estratégias de comunicação não abordados pela $\mathrm{AC}$ e na $\mathrm{AE}$. A fossilização pode ser descrita como um fenômeno linguístico que mantém, de maneira inconsciente e consistente, traços da gramática de L1 na aprendizagem de L2. Já as estratégias de comunicação ocorrem como planos conscientes que o estudante elabora para resolver um determinado problema de comunicação frente à carência linguística.

O modelo também sofreu críticas pela escassez de estudos empíricos e pelo aparato teórico considerado fragmentado. 


\section{CAPÍTULO 3}

\section{Análise dos Dados}

Neste capítulo examinaremos o corpus desta pesquisa a fim de conhecermos os erros produzidos e as estratégias as quais os aprendizes recorrem diante dos problemas de aquisição de L2. Ainda, buscaremos comprovar as hipóteses iniciais de transferência entre L1 e L2, além de buscar entender quais são os obstáculos linguísticos para falantes de língua timbira na aquisição das flexões verbais do português.

Conforme explicação anterior, o corpus desta pesquisa é composto por quarenta redações, as quais tinham como tema as tradições indígenas no passado, no presente e no futuro. As composições elaboradas pelos alunos foram divididas conforme a referência temporal aos tempos verbais mencionados. Após esta primeira divisão houve a identificação dos erros e das estratégias conforme o modelo da AE e sua classificação na porcentagem de repetição dos mesmos.

\subsection{Os erros em relação ao passado}

Começaremos esta análise considerando os erros cuja referência temporal é o passado. Já mencionamos que o termo erro aqui adotado constitui-se em um desvio linguístico transitório que também pode refletir algumas estratégias universais de aprendizado. Desta forma, reiteramos que para a AE o erro é algo útil e necessário, pois é uma característica sistemática que reflete a competência transitória em um certo momento no processo de aquisição.

\subsubsection{Classificação dos erros no tempo passado}

Quadro 4- Classificação dos erros no tempo passado

\begin{tabular}{|c|c|}
\hline ERRO & FREQUÊNCIA \\
\hline $\begin{array}{c}\text { Uso do pretérito imperfeito no lugar presente do } \\
\text { indicativo }\end{array}$ & $52,5 \%$ \\
\hline
\end{tabular}




\begin{tabular}{|c|c|}
\hline Uso do infinitivo no lugar do pretérito imperfeito & $20 \%$ \\
\hline $\begin{array}{c}\text { Uso das formas do pretérito imperfeito no lugar } \\
\text { pretérito perfeito }\end{array}$ & $15 \%$ \\
\hline Uso do pretérito pelo futuro & $10 \%$ \\
\hline
\end{tabular}

\subsubsection{Uso do pretérito imperfeito no lugar do presente do indicativo}

Neste momento, atentaremos para um erro que se manifestou em mais da metade das redações que referenciavam o pretérito, vejamos alguns exemplos:

(49) "Porque antigamente as tradições é muito valorizada[...]" T" $40, \mathrm{~L}^{11} 1$ (eram)

(50) "Antes era todos das tradições da antigamente, nós vivemos pela tradição indígena[...]" (vivíamos) T 5, L 1

(51) “[...]naquela época os índios tem própria sua cultura[...]” (tinham) T 32, L 2

Percebemos o presente do indicativo substituindo o pretérito imperfeito. Ora, já vimos no item 1.3.5 que na língua timbira há o uso de partículas na representação do aspecto durativo, diferentemente do português em que este aspecto é expresso na flexão verbal do imperfeito. Travaglia (1981) afirma que o tempo pretérito imperfeito é essencialmente durativo sendo caracterizado por apresentar a situação como tendo duração contínua limitada.

Baccili (2009) ao pesquisar a aquisição da língua portuguesa por falantes de língua kaingang (família Jê, tronco Macro-jê) apresenta um erro similar que é chamado de troca de tempo: uso do presente pelo passado. Em relação a esse erro, a autora apresenta as seguintes frases:

${ }^{10}$ Texto
${ }^{11}$ Linha 
a onça pegou o coelho e come o coelho (comeu)

mas quando na chegando minha mãe $f a z$ muitos balaios ( $f e z$ )

(2009, p. 67)

Na explicação dessas trocas de tempo verbal, a autora também se pauta na análise contrastiva e afirma que há uma transferência negativa da língua materna para a L2, pois em kaingang não há as desinências verbais indicadoras de tempo, assim, o aprendiz transfere essa regra para a L2 ao produzir as sentenças em português com a noção de tempo erroneamente empregada.

Embora haja a possibilidade de transferência negativa para os dados analisados nesta dissertação, voltemo-nos para a noção aspectual que está intrínseca ao tempo pretérito imperfeito.

Comrie (1976) distingue tempo e aspecto pelo fato de o primeiro ser uma categoria dêitica que situa as situações geralmente em referência ao momento da enunciação; já o segundo é caracterizado por não ser uma categoria dêitica e representar as diferentes maneiras de ver a constituição temporal interna da situação, ou sua duração. Desta forma, segundo o autor, o tempo se aproxima mais da constituição externa da situação e o aspecto da sua constituição interna.

Ao nos referirmos ao imperfeito do português, Travaglia (1981) afirma que este pode exprimir os aspectos durativo, cursivo e habitual.

Já o presente do indicativo, da mesma forma, expressa o aspecto imperfectivo; de acordo com Comrie (1976), tendo em vista que o tempo presente é usado frequentemente para descrever situações ao invés de narrá-las, então este é essencialmente imperfectivo. Travaglia, da mesma forma, corrobora esta afirmação e acrescenta que o presente do indicativo do português marca os aspectos indeterminado, habitual, não-acabado, cursivo e imperfectivo, em adição; em conjunto com outros meios (adjuntos adverbiais, valor do semantema etc.) esse tempo verbal também pode apresentar a situação com aspectos tais como o durativo, o pontual, o acabado e o perfectivo.

Percebemos assim que na língua portuguesa, tanto o tempo presente, quanto o pretérito imperfeito, podem expressar aspectos semelhantes. Consideramos essa similaridade importante para aquisição de PL2 e para a substituição dos referidos tempos 
verbais, uma vez que compreendemos que o aprendiz, no corpus apresentado, recorre primeiramente a estruturas que denotam o pretérito, como os advérbios e o passado simples e, em seguida, se pauta no tempo presente na tentativa de mostrar que a situação não foi pontual ou não teve seu início e término no mesmo instante. Travaglia (1981) esclarece-nos que a expressão do aspecto depende não somente de elementos morfológicos, mas também de elementos sintáticos, semânticos, fonológicos e muitas vezes contextuais.

Outra observação a favor dessa hipótese são as marcas aspectuais que são manifestadas fora da raiz verbal em L1; assim como em Baccili (2009), consideramos a hipótese de transferência negativa da língua materna para o português, pois acreditamos que os aprendizes não se atentam às noções aspectuais já contidas na flexão do pretérito imperfeito e recorrem ao presente por entenderem que este artifício pode apontar para uma situação não acabada ou não pontual.

\subsubsection{Uso do infinitivo no lugar do pretérito imperfeito}

Em relação ao uso inadequado do infinitivo, encontrado em $20 \%$ das redações, nos atentamos aos seguintes exemplos:

(52) “[...]todos dos dias ele ela pintar para a festa que faz nas aldeias” (pintava) T 7, L 3

(53) "Povo krahô do antigamente fazer uma tradições a sim" (faziam)T 8, L 1

(54) “[...]A noite começar a cantar com maracá” (começávamos)T 16, L 1

Notamos o uso do infinitivo substituindo o pretérito imperfeito. Já vimos que na língua timbira apenas alguns verbos têm sua forma modificada, as chamadas formas breves ou finitas e as longas ou não finitas. Assim, não há flexões, pois os verbos fazem uso de partículas e dos pronomes pessoais na distinção entre passado e presente.

Deste modo, podemos pensar que a escolha do infinitivo pode estar relacionada a formas não marcadas com relação ao tempo verbal e isto denuncia uma fase inicial do aprendizado de PL2.

Pires (1999), ao analisar a aquisição da morfologia verbal do português por um falante de finlandês, notou que na fase inicial de aquisição, o aprendiz em lugar de formas 
finitas, isto é, formas verbais flexionadas, usa formas não finitas ou não marcadas quanto ao tempo verbal. A pesquisadora afirma que tais construções, tanto no tempo passado como em outros tempos e modos verbais dominaram a aquisição de L2 por um curto período do processo em sua pesquisa e constituíram um tipo de erro mais recorrente da primeira fase do aprendizado.

Da mesma forma, Camara Jr. (1999) trata o infinitivo como a forma menos marcada do verbo:

O infinitivo é a forma mais indefinida do verbo. A tal ponto, que costuma ser citado como o nome do verbo, a forma que de maneira mais ampla e mais vaga resume a sua significação, sem implicações das noções gramaticais de tempo, aspecto ou modo. (2009, p.103)

Assim, o uso inadequado do infinitivo mostra que o falante não se atenta ao tempo ou não domina as regras flexionais dos verbos portugueses, pois utiliza construções indefinidas para o verbo. Além disso, tal erro pode ser analisado como um caso de transferência negativa de L1 para o L2, pois os verbos na língua materna não aparecem flexionados nos tempos verbais. Outra percepção também se manifesta quanto à fase de aquisição em que estes aprendizes se encontram, pois este erro geralmente é visto em fases iniciais do aprendizado de L2, embora os timbira cujas redações são aqui analisadas sejam considerados aprendizes intermediários da língua portuguesa, visto estarem concluindo o ensino fundamental à época da coleta dos dados.

\subsubsection{Uso do pretérito imperfeito no lugar do pretérito perfeito}

Em 15\% das redações, encontramos as trocas entre as desinências modo-temporais do pretérito perfeito e imperfeito:

(55)“No passado a gente correu todos mundo correu" (corria) T 23, L 2

(56) "No pátio os jovens aprenderam as histórias de antigamentes" (aprendiam) T 23, L 3

(57)“Na época foram grande com tradições de festa e cultura indígena” (eram )T 33, L 2 
Comrie (1976) difere o aspecto perfectivo do imperfectivo dizendo que o primeiro indica o ponto de vista de uma situação como um todo, sem distinção das várias fases que compõem tal situação, já o segundo dedica atenção especial à estrutura interna da situação. Assim, o perfectivo denota uma situação completa com começo, meio e fim enquanto o imperfectivo indica a situação em progresso.

Com relação à língua portuguesa, Camara Jr. (2009) afirma que o pretérito apresenta duas divisões: o primeiro é anterior ao outro chamado de pretérito-mais-queperfeito e que também possui um rendimento mínimo na língua oral, empregando-se em seu lugar o pretérito perfeito ou uma locução de particípio com o verbo auxiliar ter (ex: tinha cantado em substituição a cantara); a segunda, em relação ao momento da enunciação, também pode ser dividida e formar, juntamente com a noção de aspecto, o pretérito imperfeito, que assinala um processo inconcluso, ou o perfeito, que é indiferente a essa distinção. Desta maneira, diferem-se pretérito perfeito e imperfeito pela noção aspectual que está intrínseca a este último.

Kunrath (2004), ao analisar a aquisição do aspecto lexical na aquisição dos tempos verbais do passado em português como segunda língua por falantes de alemão, conclui que o pretérito perfeito é adquirido antes do pretérito imperfeito e é o tempo verbal predominante na linha principal da história que contêm os elementos narrados em sua pesquisa.

Segundo a pesquisadora, há três características temporais distintas denotadas pelos termos: tempo verbal, aspecto gramatical e aspecto lexical. O tempo verbal refere-se à dêixis temporal, a relação passado, presente ou futuro de uma dada situação com o tempo de referência ou o tempo da fala. $\mathrm{O}$ aspecto gramatical é definido como as diferentes formas de ver a constituição temporal interna de uma situação e é expresso através de marcadores gramaticais como as flexões verbais ou os auxiliares (COMRIE, 1976). Já o aspecto lexical refere-se às características temporais inerentes na concepção de uma situação expressa por um predicado na sua forma não-marcada ou lexical, independente de qualquer marcação gramatical (ROBINSON, 1995).

Os resultados da pesquisa de Kunrath mostram uma aquisição gradativa do pretérito imperfeito, o qual é influenciado pela aquisição do aspecto lexical e posteriormente do 
aspecto gramatical. Assim, é comum, nos primeiros estágios do aprendizado, a recorrência ao pretérito perfeito.

O corpus desta pesquisa também evidencia uma preponderância do pretérito perfeito em relação ao imperfeito, influenciada provavelmente, assim como no trabalho de Kunrath (2004), pela dificuldade de entendimento aspectual deste último. Podemos dizer que os indígenas estão em fase de aprendizado e que a L1, por manifestar as noções de aspecto fora da raiz verbal, também influencia na transferência negativa de parâmetros para a L2.

\subsubsection{Uso do pretérito imperfeito no lugar da perífrase verbal ir+infinitivo (futuro)}

Ainda com relação ao pretérito, analisamos as redações onde há o uso de verbos no futuro, embora os alunos quisessem se reportar a um fato passado:

(58) “Aí a gente vão fazer a festa todo mundo pintarão com pau de leite[...]”, (fazia) T 25, L2

(59) “[...]de manhã agente vai destribui o que que vam comer[...]" (distribuía, comeríamos)T 35 , L 4

(60) "Por que, quando eles vão iniciar alguns festa, todo mundo vão ser pintado o corpo de qualquer jeito" (iniciavam, seria)T 12, L 1

Nessas produções, notamos o uso da perífrase verbal 'ir + infinitivo' no tempo futuro, quando o correto seria a colocação do pretérito imperfeito ou a referência a este tempo em perífrases verbais (ia fazer, ia distribuir, ia comer, ia iniciar, íamos comer).

Castilho (2010), ao se reportar sobre os gêneros discursivos em língua portuguesa, afirma que as perífrases predominam sobre as formas verbais simples na expressão do imperfectivo. Segundo o autor, entre as perífrases que veiculam aspecto, num total de 93 ocorrências, 65 são gerundiais, 32\% são participiais e apenas 3\% são de infinitivo. Ainda, de acordo com seu trabalho, estas últimas muito provavelmente expressam o tempo futuro. 
Além disso, Travaglia (1981) mostra que é comum, dependendo do significado do verbo principal ou do tempo em que está o verbo 'ir', termos não uma perífrase marcadora de futuridade, mas sim o verbo 'ir', indicando locomoção para um lugar onde se realiza o indicado pelo verbo no infinitivo. Ainda, o autor nos mostra que nas frases em que ir + infinitivo deixa de marcar tempo futuro, temos a expressão de aspectos devido à flexão temporal e a outros meios, como o adjunto adverbial; assim a frase: Todo dia ela ia regar a horta para mim denota os aspectos imperfectivo, não-acabado e habitual.

Deste modo, ponderamos que tal erro seria uma tentativa de marcar o aspecto imperfectivo, ainda não sistematizado pelos aprendizes.

\subsubsection{As estratégias usadas no tempo passado}

Segundo o modelo da $\mathrm{AE}$, os estudos baseados no erro tendem a apontar as estratégias que os aprendizes usam na aquisição de L2, além de informarem as dificuldades comuns no aprendizado. Neste tópico discorreremos sobre o que classificamos como estratégias, por entendermos que estas ocorrem como planos conscientes que o estudante elabora para resolver um determinado problema de comunicação frente à carência linguística. Vejamos como os alunos as usam para se referirem ao passado:

Quadro 5 - As estratégias usadas no tempo passado

\begin{tabular}{|c|c|}
\hline ESTRATÉGIA & FREQUÊECIA \\
\hline $\begin{array}{c}\text { uso de advérbios como auxiliares para } \\
\text { marcação do tempo em início de tópico }\end{array}$ & $80 \%$ \\
\hline uso da memória coletiva & $20 \%$ \\
\hline $\begin{array}{c}\text { uso do presente histórico (um período } \\
\text { completo realizado no tempo presente) }\end{array}$ & $17,5 \%$ \\
\hline
\end{tabular}




\subsubsection{Uso de advérbios como auxiliares para marcação do tempo em início de tópico}

Em $80 \%$ das redações, constatou-se o uso de advérbios como auxiliares para a marcação temporal. Na referência ao passado, os advérbios possuem uma função estratégica importante nas redações, pois em muitos casos somente eles é que identificam esse tempo verbal. Vejamos alguns exemplos:

(61) “Antigamente, os povos indígena fazer a festa e todos pintarão no corpo com jenipapo e urucu passa no corpo também E fazendo também chapel de folha de burite, coloca no pescoço também" $" 12$ T 14, L 1

(62) "Sim Antigamente os índios velhos que não tem lugar certos para mora na aldeia. Mas premeiro festa para fica alegre para corre mas premeiro. A gente vai pintar com jenipapo e pau -de -leite e urucum. Quando vai para corre vai ser muito sol quente da atarde mas sempre corre embaixo" 13 T 11, L 3

Nessas redações, como em outras similares, o tempo passado é somente identificado pelo uso do advérbio, deste modo as flexões verbais possuem um papel secundário ou não ajudam para a compreensão de referência ao pretérito.

De acordo com Castilho (2002) os advérbios da língua portuguesa podem ser classificados segundo critérios tradicionais que podem variar entre morfológicos, sintáticos e nocionais. Na definição morfológica, o advérbio é conhecido como palavra invariável e modificador que se aplica a não substantivos. Já seguindo definições sintáticas, vemos que o advérbio se comporta como uma palavra relacionada sintaticamente ao verbo, ao adjetivo ou a outro advérbio. Por último, nos critérios nocionais é apresentada a função de modificadores que os advérbios transmitem, pois segundo o autor, as relações sintáticas têm por correlato semântico a modificação do sentido das palavras, assim têm-se o advérbio como modificador da ideia expressa pelo verbo ou o causador das 'circunstâncias' em que se dá o processo a que ele faz referência.

\footnotetext{
${ }^{12}$ Antigamente os povos indígenas faziam a festa onde todos pintavam no corpo com jenipapo e urucu que eles passavam no corpo também. Faziam ainda, chapéu de folhas de buriti e colocavam no pescoço também.

${ }^{13} \mathrm{Sim}$, antigamente os índios velhos que não tinha lugar certo para morar na aldeia, faziam primeiro a festa para ficar alegre e correr. Primeiro a gente pintava com jenipapo pau de leite e urucum. Quando a gente ia correr já era o sol quente da tarde, mas a gente sempre corria embaixo.
} 
Na língua timbira ainda são escassos os trabalhos sobre o uso de advérbios. Entretanto destaca-se a pesquisa de Ferreira (2003), que analisa para o parkatejê diferentes classes de palavras que podem funcionar como advérbios; essas classes indicam expressões dêiticas, entre outras noções. Segundo a autora, vários advérbios podem ser derivados de nomes, por exemplo, nomes inalienavelmente possuídos como katut 'costas' ou $\boldsymbol{h}$-arkwa 'rel-boca' que podem ocorrer como modificadores verbais, assumindo os significados de 'atrás' e 'frente', respectivamente. Além disso, os descritivos, os numerais e os quantificadores são, da mesma forma, usados como modificadores verbais. A autora destaca ainda uma subclasse de advérbios que inclui os locativos e os temporais.

Para estudo das relações de tempo abordadas nesta pesquisa nos atentaremos aos advérbios temporais, os quais, de acordo com Ferreira, podem ser definidos por nomes relacionados a tempo, referentes a parte de um dia e a períodos mais curtos ou mais longos de tempo, marcados, em sua maioria por posposições. A autora também apresenta um quadro de advérbios temporais:

Quadro 6 - Advérbios temporais (Ferreira, 2003, p.146)

\begin{tabular}{|c|c|}
\hline ADVERBIAL & GLOSSA \\
\hline nõ kõm & 'ontem' \\
\hline apẽ ñ̃ & 'hoje' \\
\hline ita kõm & 'dia' \\
\hline aikati & 'noite' \\
\hline aikapët & 'cedo' \\
\hline kokrën & 'antes' \\
\hline mama & \\
\hline
\end{tabular}

É importante também a maneira diferenciada que os Parkatêjê se referem sobre a extensão do tempo, conforme Ferreira:

Os parkatêjê, até onde pude investigar, falam da extensão do tempo, se for necessário, explicitando o momento inicial e o momento final da ação. Não consegui obter expressões como 'a noite toda', 'o dia todo', um ano inteiro, 
'um dia inteiro', 'dois meses', tampouco me foi possível averiguar se já houve uma forma de marcar o tempo do calendário com os nomes e os dias da semana e dos meses do ano, e o tempo do relógio em horas e minutos. Os parkatêjê tinham sua maneira própria de contar o tempo, que não era por meio das noções de mês ou ano, segundo informantes mais idosos, mas sim por meio de verões. Entretanto eles já não sabem explicitar ao certo qual era essa maneira de contar o tempo, visto que já não recordam esse método. (2003, p.146)

Segundo Alves (2004), em apãniekrá os advérbios de lugar e tempo na língua são palavras compostas por um dêitico seguido por uma posposição. Os dêiticos que indicam tempo são vários, enquanto que as posposições que os seguem são ou a locativa $\{$ kãm $\}$ ou a posposição ainda sem definição $\{$ nã $\}$ :

apãniekrá (ALVES, 2004, p.79)

\begin{tabular}{|c|c|}
\hline$i ?$ & $n \tilde{\widetilde{\tau}}$ \\
\hline 3 & $\begin{array}{c}\text { IND } \\
\text { 'ontem' }\end{array}$ \\
\hline$a p \tilde{\varepsilon}$ & $n \tilde{a}$ \\
\hline & $\begin{array}{l}\text { POSP } \\
\tilde{a}^{\prime}\end{array}$ \\
\hline
\end{tabular}

Embora tenhamos alguns indícios do funcionamento dos advérbios em timbira, não encontramos nos trabalhos mencionados um advérbio ou locução adverbial que indique um período de tempo no passado como é o caso de antigamente, ou no passado. Ferreira (2003) corrobora com esta afirmação ao discorrer sobre a dificuldade de encontrar expressões que indiquem um período de tempo como: um ano inteiro, a noite toda, dois meses. Ainda ao discorrer sobre a presença da partícula $\{$ t $\varepsilon\}$ no tempo passado a autora cita que Araújo (1989) argumenta que esta partícula é apagada em orações que fazem um relato remoto, o qual é indicado pelo argumento temporal ajkumẽ (antigamente), pois a noção de passado já está expressa por esse argumento e o aspecto não vem ao caso.

Diante dessas considerações, o que parece ocorrer no corpus é que, devido à presença dos advérbios de L2, os quais já expressam a noção de duração de tempo no 
passado (antigamente, no passado, antes), os aprendizes não se atentam às flexões verbais da língua. Assim não entendem a necessidade de flexionar os verbos no passado porque já marcaram através de um advérbio a referência ao tempo pretérito.

Katamba (1993) diz que o que será expresso pela flexão morfológica passa por interpretações subjetivas e depende da cultura em questão:

Que diferenças em significado ou função sintática são consideradas suficientemente importantes de serem expressas pela flexão morfológica é algo que parece estar aberto a interpretações subjetivas e depende da cultura. $(1993, \text { p. } 214)^{14}$

Nesse caso, é necessário compreender toda a oração das redações analisadas para entendermos a qual tempo verbal se refere o sintagma.

Castilho (2002) também se reporta aos critérios nocionais dos advérbios, que conforme visto anteriormente, possuem a função de modificadores da ideia expressa pelo verbo ou o causador das 'circunstâncias' em que se dá o processo a que ele faz referência. Desta forma percebemos que tal classe de palavras transmite uma noção temporal que norteia toda a frase e talvez seja por isso que, para os aprendizes de PL2, os advérbios já contenham em si a referência temporal, não havendo a necessidade da correlação verbal.

\subsubsection{Uso da memória coletiva}

Nas construções do passado visualizamos que os indígenas em $20 \%$ das redações recorriam ao uso da memória coletiva ou a alusão às histórias dos antepassados:

(65) “[...] os mais velhos contam assim [...]” T 1, L 1

(66) “[...]Ijõ jajá comta esta história [...]” T 24, L 1

(67) “Eu vou contar uma história que meu avô contou para mim [...]” T 30, L 1

\footnotetext{
${ }^{14}$ What differences in meaning or syntactic function are considered sufficiently important to be expressed by morphological inflexion is something that seems to be open to subjective interpretation and to depend on culture.
} 
Consideramos esse recurso como uma estratégia de referenciação ao passado distante, ou a um passado remoto, só conhecido pela memória coletiva e pela tradição oral transmitida de geração em geração na aldeia.

De acordo com Amado (2009, p.36) "tal recurso é próprio da fala de povos de cultura predominantemente oral, cujas tradições são ratificadas pela autoridade dos antepassados". Esta estratégia também revela a cultura oral embutida na prática da escrita entre os timbira, pois a tradição histórica, própria da sociedade letrada, também se encontra em um processo de implementação. Ferreira Neto (2008) aponta que o meio utilizado pelas sociedades de tradição oral é a oralidade, valendo-se da memória coletiva e individual, já o das sociedades de tradição escrita são os documentos permanentes, sejam eles escritos ou não, estabelecendo a memória histórica.

Santos (2011) analisa a tradição oral na educação escolar dos Wajãpi (grupo Tupi) e também detecta o uso da memória coletiva. De acordo com esta autora, em sociedades de tradição oral, a memória coletiva é o repositório de todo o saber constituído social e historicamente pelo grupo, nada mais natural, portanto, que os indivíduos que dela compartilham, recorram a ela para elaborarem seus discursos. Nos textos analisados por Santos, há igualmente a menção à fonte de informação como em timbira, visto que os aprendizes citam de onde, ou por meio de quem tiveram acesso a tais narrativas: 'os mais velhos', 'Ijõ jajá', 'meu avô'. Para Santos, essas indicações exemplificam o fluxo da memória coletiva pelo qual as informações são transmitidas entre as gerações. O fluxo é mantido porque elas estão sendo narradas por aqueles que outrora compuseram sua audiência.

\subsubsection{Uso do presente histórico}

Em 17,5\% das redações percebemos o uso do tempo presente em um período completo de referência ao passado. Tal erro se distingue do uso do presente do indicativo no lugar do pretérito imperfeito, porque nesse caso os aprendizes usam orações completas no tempo presente, o que não ocorre no primeiro caso. Ao analisarmos esta recorrência notamos que os indígenas se pautaram no uso do presente histórico do português ou a utilização do presente com valor de passado, vejamos: 
(68) primeiro, os índios anda em nu, com folha patras e pra frente. Os índios se alimentam em pau padre no antigamente, eles vivem assim, anda mas eles se pinta, urucu, paudi leite. Também índios não esquece os usu deles nas festa, eles comes umas coisa só ${ }^{15} \mathrm{~T} 24, \mathrm{~L} 1$

(69)Antigamente o meu povo canta no pátio a noite inteiro para que eles não esquecer da cultura tradicional que os mas velhos encinavam para eles, e quando começa a festa tradicional todos vão para o pátio ${ }^{16} \mathrm{~T} 28, \mathrm{~L} 1$

(70)[...]porque homem e mulher corre com a tora quando chegar na aldeia começa a canta esse é nosso tradição e ritual que a gente tem na aldeia. O povo trabalha de grupo na roça para ter muito alimento ${ }^{17} \mathrm{~T} 39, \mathrm{~L} 1$

Camara Jr. (2009) define o presente histórico como o uso de formas não marcadas para o pretérito e salienta que seu emprego é mais comum na linguagem oral. Já vimos anteriormente que a prática da oralidade é comum entre as etnias timbira e que vestígios desta prática também norteiam o corpus deste estudo. De acordo com os manuais de gramática, como o de Cunha e Cintra (2001), o presente histórico serve para dar vivacidade a fatos ocorridos no passado ou para causar no interlocutor a impressão de uma realidade atual, chamando-o a integrar-se, por meio da imaginação, ao momento do fato descrito.

Ladeira (2005) ao refletir sobre o uso da oralidade entre os timbira nos apresenta a seguinte observação:

A oralidade implica uma memória enquanto presença de si consigo mesma e enquanto duração a transmissão oral exige a presença do outro como interlocutor. Ela não aprisiona a duração (o tempo de) por meio da escrita. A transmissão dos conhecimentos através desta memória oral não permite distâncias, a noção de tempo histórico, que a memória escrita instaura. A memória escrita cria a possibilidade do passado e coloca, por si só, a questão do futuro. Se pensa o tempo, se constrói o tempo. Não se pensa o futuro sem se criar o passado. (2005, p.14)

\footnotetext{
15 Primeiramente, os índios andavam nus com folhas para trás e para a frente. Os índios se alimentavam em pau podre antigamente, eles viviam assim:, andavam e se pintavam de urucu e pau de leite. Também os índios não se esqueciam dos usos deles nas festas, eles comiam uma coisa só.

${ }^{16}$ Antigamente o meu povo cantava no pátio a noite inteira para que eles não se esquecessem da cultura tradicional que os mais velhos ensinavam para eles e quando começava a festa tradicional todos iam para o pátio.

${ }^{17}$ Porque os homens e as mulheres corriam com a tora quando chegavam lá na aldeia e começavam a cantar, essa é a nossa tradição que a gente tinha na aldeia. O povo trabalhava em grupo na roça para ter muito alimento
} 
Ao analisarmos estes conceitos, podemos pensar sobre a complexidade do domínio do letramento entre os indígenas, pois, conforme Ladeira, a transmissão oral não aprisiona a duração do tempo por meio da escrita.

Acreditamos que os indígenas utilizam o presente histórico nas redações, pois este é o tempo verbal das narrativas e de sua tradição oral. Através deste tempo há a integração com o outro e o convite à prática da imaginação. Assim, os aprendizes não utilizam as flexões verbais do português formal escrito por transporem nas redações a maneira com que tratam e relacionam o tempo na oralidade.

\subsection{Os erros em relação ao presente}

Neste tópico abordaremos os erros relacionados ao tempo presente. Ponderamos que este tempo verbal revela-se ser mais compreendido pelos timbira, pois maiores foram as porcentagens de acertos comparados com os erros cometidos pelos estudantes e muitos destes últimos são similares aos erros do tempo passado. Ainda detectamos o uso de uma estratégia já analisada anteriormente.

Quadro 7 - Os erros em relação ao tempo presente

\begin{tabular}{|c|c|}
\hline Erro & FREQUENCIA \\
\hline Uso do presente no lugar infinitivo & $25 \%$ \\
\hline Uso do presente no lugar do gerúndio & $12,5 \%$ \\
\hline Uso do presente no lugar pretérito & $7,5 \%$ \\
\hline
\end{tabular}




\subsection{1 - Uso do presente no lugar do infinitivo}

Examinemos os exemplos desse erro encontrado em $25 \%$ das redações:

(71)“[...]quando tem a festa na aldeia só o velho participar, e o jovem fica dentro da casa curtindo música[...]” (participa)T 1, L 6

(72) 'Porque só ce acaba com a nossas cultura que os meus bisavós nós usar, que na minha você não ver os jovens cortando os cabelos como os cupê cortam[... ${ }^{18}$ (usamos, vê)T 4, L3

(73)““...]quando os comunidade vamos fazer outros festa os juventude não ajudar de corre[...]" (ajuda) $)^{19} \mathrm{~T} 11, \mathrm{~L} 7$

No tópico (3.1.2), relacionado ao tempo passado, analisamos o uso incorreto do infinitivo e vimos que o mesmo é influenciado pela transferência negativa, bem como pelo estágio inicial do aprendizado de PL2.

Sabemos que o infinitivo em português é considerado uma forma verbo-nominal que designa o processo em si mesmo, sem referência clara ao momento de sua realização, ao contrário do que acontece nas formas verbais propriamente ditas, as quais possuem sufixos indicadores de tempo.

Cunha e Cintra (2001) caracterizam o infinitivo como apresentador de uma forma verbal em potencial que exprime a ideia da ação e, por isso, se aproxima de um substantivo. Além disso, a forma do infinitivo impessoal, segundo os autores, ou sua forma não flexionada,é empregada quando ela não se refere a nenhum sujeito, quando em frase nominal de acentuado caráter afetivo houver sentido narrativo ou descritivo, quando precedido das preposições de ou regido da preposição $a$, entre outras formas como em locuções verbais ou quando dependente de auxiliares acusativos.

Baccili (2008) descreve um erro similar de uso do infinitivo ao analisar a aquisição da flexão verbal do português por falantes de língua kaingang:

\footnotetext{
${ }^{18}$ Porque só acabam com as nossas culturas que meus bisavós e nós usamos, porque na minha (aldeia) você não vê os jovens cortando os cabelos como os cupê cortam. (cupê = não índios)

${ }^{19}$ Quando a comunidade vai fazer outras festas a juventude não ajuda a correr.
} 
‘ela fazer comida pra mim’ (faz)

'eu procurar comida para minha passarinho' (procuro)

' e a minha mãe pegar muito peixe' (pega)

(2008, p. 63)

Em análise a esses erros, a autora se baseia no aspecto da língua kaingang o qual não utiliza nenhuma marca formal, ou nenhuma desinência no verbo em sua caracterização. Segundo a pesquisadora, o uso do infinitivo está relacionado à existência dessas formas verbais não alteráveis, pois o aprendiz transfere essa estrutura para o português e, portanto, utiliza a forma infinitiva do verbo em todas as sentenças.

Embora seja considerável a análise de Baccili, refletimos que o aspecto é de ordem secundária em análise a este erro, concordando com o que nos apresenta Travaglia (1981) ao afirmar que o infinitivo é aspectualmente neutro e não atualiza qualquer noção aspectual, quer na forma não flexionada, quer na forma flexionada. Ainda, argumentamos que o uso do infinitivo está relacionado ao estágio inicial de aprendizado, conforme Pires (1999) analisa para a aquisição do verbo por falantes de finlandês. Igualmente, devido a esta fase primária o falante timbira recorre ao uso de formas verbais não flexionadas, que não se referem a nenhum sujeito e não possuem referência clara ao momento de sua enunciação.

\subsubsection{Uso do presente no lugar gerúndio}

O uso do gerúndio no lugar do presente simples foi detectado em 12,5\% das redações abordadas:

(74) 'Ainda nós tem nossa cultura e preservando e aprendendo com os mais velhos que conta a história[...]' (preservamos, aprendemos) T 6, L 5

(75) 'Até agora nós sempre relembrando os passados, nunca nós deixamos as tradições dos kraolandios' (relembramos) T 19, L 11 
(76) ‘[...]porque nós seguindo nossa tradições antiga que os mais velho tem para repassa para os mais novo[...]' (seguimos) T 29, L 1

De acordo com Travaglia (1981) o presente do indicativo expressa aspecto imperfectivo e apresenta a situação sempre com aspecto não acabado ou começado. Em adição, o aspecto cursivo, da mesma forma, é expresso por este tempo verbal em descrições simultâneas e principalmente na linguagem oral mais formal ou na escrita, que é sempre mais formal que a fala. Já o gerúndio normalmente é apontado como marcador dos aspectos não acabado, cursivo e durativo.

Partindo destas considerações, observamos que tanto o presente do indicativo quando o gerúndio expressam os aspectos não acabado e cursivo e tal proximidade de manifestação aspectual mostra-se importante na aquisição de PL2.

Já analisamos, anteriormente, as dificuldades de aquisição do aspecto no tempo passado pelos timbira e vimos que esse é substituído por variadas formas verbais inadequadas na tentativa de sua expressão. Assim, em razão da não aquisição desta categoria verbal de tempo, e por este ser manifestado através de partículas na língua dos aprendizes, ponderamos que este erro também se relaciona com o não entendimento das categorias aspectuais da língua portuguesa, pois os estudantes utilizam o gerúndio como forma de remeterem a algo não acabado em que a situação está em pleno desenvolvimento, aspectos estes mais bem representados em L2 pelo presente do indicativo.

Outra possível hipótese, embora este trabalho não trate propriamente de questões relacionadas à fonologia, é a proximidade fonológica da terminação $\{$ ando $\}$ e $\{\operatorname{mos}\}$, principalmente no que tange à nasalidade. No corpus em questão este erro foi detectado, em sua maioria, em alusão à primeira pessoa do plural ou P4 (o falante e mais alguém); assim, poderíamos também refletir que houve a inserção do segmento coronal /d/ devido a similaridade das terminações, que mantém o mesmo número de sílabas na palavra. Como os estudantes estão em fase de aquisição das flexões verbais do português, é possível que estas sejam confundidas com as desinências número-pessoais de L2 pela proximidade fonológica. 


\subsubsection{Uso do presente no lugar do pretérito}

Passemos à análise de um erro que ocorreu em 7,5\% das elaborações:

(77) 'Mais agora nesses dia nesses anos de 2006 já ta quais índios não lembrou os costumes' (lembram)T 11, L 6

(78) 'Agora os jovens já não usava aquela tradição que os velhos usavam premeiramente' (usam) T 21, L 3

(79) 'Mas hoje sempre os homens juntamos no pátio conbinavam a fazer a festa' (combinamos) T 25, L 6

Nos exemplos, notamos a substituição do presente pelo pretérito. Entretanto, vemos que este uso está relacionado com a estratégia de uso de advérbios como marcadores de tempo em início de tópico, pois os aprendizes de L2 referenciam o tempo através advérbios tais como: Hoje, Sempre, Agora, Nesses dias, Nesses anos.

Anteriormente no tópico 3.2.1 analisamos a manifestação deste uso e concluímos que o que parece ocorrer no corpus é que, devido à presença dos advérbios de L2, os quais já expressam a noção de duração de tempo, os aprendizes não se atentam às flexões verbais da língua. Assim, da mesma forma que no tempo passado, os estudantes não entendem a necessidade de flexionar adequadamente os verbos porque já marcaram através de um advérbio que o que eles estão se referindo é o tempo presente

\subsection{Tempo futuro: as estratégias utilizadas}

A menção a um tempo futuro mostrou-se com menor índice de produção nas redações, visto que em 55\% das mesmas, os indígenas não se reportaram a este tempo verbal, mesmo tendo sido solicitado no tema da redação. Entretanto, notamos algumas estratégias nas 17 elaborações, as quais foram passíveis de análise. 
Quadro 8 - Tempo futuro: as estratégias utilizadas

\begin{tabular}{|c|c|}
\hline $\begin{array}{c}\text { Uso de marcadores verbais para iniciar um } \\
\text { tópico }\end{array}$ & $23 \%$ \\
\hline Uso da perífrase ir + infinitivo & $100 \%$ \\
\hline
\end{tabular}

\subsubsection{Uso de marcadores verbais para iniciar um tópico}

Neste tópico, atentemo-nos para a estratégia de uso de marcadores verbais ocorrida em $23 \%$ das redações:

(80) "Mas eu penso no futuro eu não vou deixar meu povo perder a sua tradição" T 7, L 9

(81) "E eu penso assim, eu acho criança que vem em depois, vai perder a nossa cultura.

Porque já estavam usando a camisa e short". T 13, L 5

(82) "Eu vou fazer a redação sobre futuro, no meu pensamento que eu penso no

futuro, como eu estou estudando de português e matemática, ciência, geografia, e quando eu aprender de todos matérias que eu estudo na escola, e depois eu começo ganha um emprego para trabalhar com próprio mehi, na aldeia cachoeira e para defende meu povo. Só isso que eu estou pensando no meu pensamento de futuro". T 15, L 1

A estratégia do uso de marcadores verbais para o início do tópico foi encontrada, nesta pesquisa, quando os indígenas se reportaram ao tempo futuro. Ladeira (2001) e Amado (2009) detectaram tal manifestação na análise da escrita de bilhetes e diários e em redações timbira.

De acordo com Ladeira (2001) esse recurso é importante enquanto construtor, não somente do sentido, mas também da estrutura do texto. Além disso, os marcadores confirmam que, na construção de um texto escrito, os timbira têm como referência o universo do discurso formal oral.

É interessante que este recurso foi detectado nas redações, somente em referência ao tempo futuro, assim acreditamos que ele está, neste caso, intimamente relacionado à alusão 
ao pensamento em situações prováveis, embora a reflexão esteja sendo feita no presente eu penso no futuro, eu estou pensando no meu pensamento do futuro.

Sabemos que o tempo futuro do presente do indicativo em português é empregado para indicar fatos incertos ou prováveis, posteriores ao momento em que se fala. No caso da língua timbira vimos que este é representado pela partícula $\{$ ha $\}$ cuja referência também pode ser modal, ou seja, também pode se remeter a situações incertas, duvidosas, eventuais e até mesmo irreais. Partindo destas considerações, podemos pensar, também, entre outros motivos já mencionados por Ladeira (2001), que o uso de marcadores no tempo futuro auxiliam o pensamento de situações incertas, prováveis ou não. Assim o falante reafirma através desses marcadores que o que ele escreve é um pensamento, ou uma suposição.

\subsubsection{Uso da perífrase verbal: $i r+$ infinitivo}

Em relação à forma verbal simples do futuro do presente do português, é sabido que este é composto por: $\operatorname{Rad}^{20}+\mathrm{SMT}^{21}\left\{\mathrm{re}^{22} / \mathrm{rá}^{23} / \mathrm{ra}^{24}\right\}+\mathrm{SNP}^{25}$ (CASTILHO, 2010). Deste modo, podemos empregá-la para indicar fatos incertos ou prováveis posteriores ao momento da fala; para exprimir a incerteza sobre fatos atuais; como forma polida de presente; como expressão de súplica, de um desejo, ou de uma ordem; e nas afirmações condicionadas, quando se referem a fatos de realização provável. Segundo Cunha e Cintra (2001) na língua falada o futuro simples é de uso relativamente raro, deste modo, os falantes nativos de português brasileiro preferem substituí-lo pela locução formada pelo presente do indicativo do verbo ir + infinitivo do verbo principal, indicando uma ação futura imediata.

Em aprofundamento ao uso mencionado, Fonseca (2010) afirma que, para a formação da perífrase verbal ir+infinitivo, codificadora de futuridade, o verbo pleno ir, através de um processo de gramaticalização, sofreu um "esvaziamento semântico" do seu

\footnotetext{
${ }^{20}$ Radical: contém a raiz (elemento irredutível e comum a todas as palavras de uma mesma família) e elementos afixais.

${ }^{21}$ Sufixo modo temporal

${ }^{22} \mathrm{P} 1$ e $\mathrm{P} 4$

${ }^{23} \mathrm{P} 2$ e $\mathrm{P} 3$

${ }^{24} \mathrm{P} 5$ e P6

${ }^{25}$ Sufixo número pessoal
} 
significado original de deslocamento e foi recategorizado como verbo auxiliar, exprimindo noção de futuridade, quando seguido de um verbo principal. Ainda a autora menciona Silva (2002), que alerta que, embora haja esse esvaziamento semântico, é o movimento implícito em ir que dá ideia de posterioridade.

Em adição, Fonseca (2010) destaca a multifuncionalidade dessa perífrase verbal ao identificar a atualização de três tipos de aspecto nessa construção, a saber: o iterativo, o perfectivo e o imperfectivo. Sobre sua função temporal, a pesquisadora destaca a atualização do tempo futuro imediato e do futuro do pretérito, sendo o primeiro a leitura predominante em ocorrências em que o verbo aparece flexionado no presente do indicativo e em que o falante compromete-se com o valor de verdade do enunciado, conforme se verifica na construção:

olha ele (quarto) ainda num tá pronto ele vai reformá(r) TOTALMENTE né? ele vai mudá(r) MUITO mas eu vô(u) falá(r) como é que ele tá agora...

(FONSECA, 2010, p.52)

Já o segundo, de acordo com Fonseca, manifesta-se em situações em que o verbo ocorre no pretérito imperfeito do indicativo e em que o grupo verbal é parafraseável pelo futuro do pretérito. Deve estar também presente o traço [+asseverativo]. Essa função pode ser identificada em:

um moleque maior falô(u) que ia batê(r) nele na hora do recreio... por motivo num sei o que lá e brincade(i)ra lá e começô(u) empurrá(r) ele...

(FONSECA, 2010, p.52)

Além dos usos apresentados, a perífrase ir + infinitivo também atua na função modal, visto que ela faz parte de construções não-asseverativas, pois o falante não está certo quanto à realização do estado-de-coisas, projetando muito mais seu "querer" e uma "expectativa" do que a localização de um evento em momento posterior ao momento da fala, não sendo possível, portanto, reconhecer função predominantemente temporal, mas modal. Assim, devido às funções citadas, podemos compreender o processo de gramaticalização desta perífrase verbal e suas diferentes funções na língua portuguesa. 
Em contraposição, anteriormente vimos que no timbira a partícula $\{$ ha $\}$ é a responsável pela marcação da futuridade; entretanto, Souza (1997) destaca uma partícula aspectual $\{\mathrm{ma}\}$ que, juntamente com o tempo presente, pode atuar na alusão ao futuro imediato:

krahô (SOUZA, 1997, p. 38)

$\begin{array}{ccc}k e & \text { ma } & \text { mô } \\ 3 & \text { DIR ir' } & \end{array}$

Desta forma, a língua timbira também poderia se referir ao futuro imediato através uso do tempo presente. Alves (2004) corrobora com esta afirmação nos exemplos de número 21 e 22 do item 1.3.4, mencionado nesta pesquisa.

Percebemos, através dessas considerações, que é compreensível a estratégia do uso da perífrase verbal ir + infinitivo, visto que, embora esperássemos algum indício de aquisição do sufixo temporal rá e seus alomorfes (por se tratar da linguagem escrita do português), a multifuncionalidade dessa perífrase, sua gramaticalização em língua portuguesa e a escolha que parece ser advinda da informalidade na aquisição de L2, contribuem para que os timbiras atribuam somente a ela o papel de marcador de tempo futuro. 


\section{CONSIDERAÇÕES FINAIS}

O intuito desta dissertação foi discorrer acerca da aquisição da morfologia verbal do português como segunda língua entre as comunidades timbira, visto que foi notado um grande número de desvios do português padrão na análise das redações que compõem o corpus deste estudo. Objetivando este fim, esta dissertação está dividida em três capítulos que tratam do povo e da língua timbira, das teorias de aquisição escolhidas como

fundamentação teórica e da análise dos dados selecionados e subdivididos em erros e estratégias de aquisição.

No primeiro capítulo apresentamos as etnias que compõem o complexo timbira e discorremos acerca dos traços culturais que marcam a unidade das oito etnias do complexo em questão. Consideramos, para fins deste estudo, a unidade linguística do povo timbira, embora ainda haja discussões acerca deste tema. Como participação efetiva na análise dos dados, foram utilizadas as variantes das etnias pykobjê, apãniekrá, krahô e parkatêjê, visto que somente essas etnias detêm de trabalhos linguísticos significativos sobre aspectos morfológicos. Assim, podemos refletir que os apontamentos fonológicos e morfológicos desta dissertação não compreendem a totalidade da língua timbira, mas sim dos estudos passíveis de análise até o presente. Desta forma, ponderamos que a reunião de aspectos linguísticos dessas variantes não é algo acabado e imutável, mas sim uma tentativa de entender a estrutura da língua materna e seu funcionamento. Além disso, reiteramos que a reunião dos trabalhos mencionados ao longo deste estudo é de caráter descritivo cabendo aos mesmos esclarecimentos sobre os aspectos lingüísticos apresentados.

No segundo capítulo discutimos sobre as teorias de aquisição que fundamentam este estudo e compõem a base teórica para a análise dos dados. Vimos, desta forma, que a Análise Contrastiva (AC), ajudou na comparação entre a língua materna e a língua alvo, principalmente no conceito de transferência o qual justificou muito dos problemas de escrita de L1; já a Análise de Erros (AE) contribuiu para divisão e classificação dos desvios do português padrão encontrados nas elaborações timbira e, posteriormente, para a subdivisão em estratégias de aprendizados e erros de aquisição. Além disso, apresentamos a teoria da Interlíngua, que, embora não tenha sido tratada propriamente, juntamente com as 
teorias citadas, compreende uma importante ferramenta para o estudo da aquisição de línguas.

O terceiro capítulo discorre sobre a análise do corpus da dissertação e sobre as estratégias e os erros cometidos pelos alunos timbira. Esta primeira subdivisão em estratégias de aprendizado e erros de aquisição foi importante para caracterizar que muitos desvios são passíveis de compreensão e não podem ser considerados desacertos, mas sim estruturas às quais o falante recorre frente à carência dos mecanismos de L1.

Com relação aos erros classificados neste estudo, notamos que os alunos recorrem a variadas formas errôneas de usos dos tempos verbais e que estas construções apontam, essencialmente, para a não aquisição do aspecto verbal do imperfeito em língua portuguesa, é o caso do uso do passado no lugar do futuro, das formas do pretérito imperfeito no lugar do perfeito, do presente no lugar infinitivo, entre outras. Ainda, alguns desvios mostram um estágio inicial de aquisição da linguagem, conforme visto no uso do pretérito imperfeito pelo perfeito e no uso do infinitivo no lugar do pretérito imperfeito.

Notamos, além do exposto, que as estratégias encontradas nos dados denunciam a interferência de L1 na aquisição de L2, principalmente no que se refere à cultura da oralidade, é o caso do uso da memória coletiva e do uso do presente histórico. Deste modo, pudemos observar que a aquisição do português entre os indígenas é algo peculiar, que passa por suas tradições e seu modo de visualizar o mundo. Assim, ao olharmos para o aprendizado de línguas sob uma perspectiva inclusiva de L1, podemos refletir que a língua materna pode ser uma importante ferramenta para a aquisição da língua alvo, visto que as estratégias e os erros dos alunos tendem a servir de ponto de partida para um aprendizado efetivo da língua portuguesa.

Por fim, este estudo alcançou sua expectativa inicial de abarcar as dificuldades de aquisição dos tempos verbais do português por falantes de línguas timbira e mostrou muito sobre as interferências que a língua materna pode causar na língua alvo. Além disso, pudemos observar que alguns desvios também ocorrem em outros ambientes, como na aquisição do português por falantes de outras línguas como o Finlandês e o Alemão, além de etnias de outros troncos linguísticos como o Kaingang. Assim, esperamos que os resultados aqui apresentados possam ser úteis para ampliar a discussão acerca da aquisição do português como L2 e como língua estrangeira, a partir de uma perspectiva que reforce as 
discussões sobre ensino/ aprendizagem e que considere positivo o uso e o entendimento da língua materna no aprendizado da língua alvo. 


\section{REFERÊNCIAS}

ALVES, F. C. O Timbira falado pelos Canela Apãniekrá: uma contribuição aos estudos da morfossintaxe de uma língua Jê. 2004. Tese (Doutoramento em Linguística) - Unicamp, Campinas, 2004.

. Tempo, aspecto e modalidade em Canela. ReVEL, v. 7 n. 3, 2009. Disponível em: www.revel.inf.br. Acesso em 06.04.2011

AMADO, R. S. Aspectos morfofonológicos do Gavião-Pykobjê. Tese (Doutoramento em Semiótica e Linguística Geral) - Faculdade de Filosofia, Letras e Ciências Humanas, Universidade de São Paulo, São Paulo,2004.

A grafia uniformizada: uma conquista dos povos Timbira. Linha D'Água, São Paulo, v.17, p.65-75, 2005.

Notas sobre o alongamento vocálico em Pykobjê. In: VII Encontro dos Alunos de Pós-Graduação em Linguística da USP, São Paulo, 2006.

- Marcas da oralidade timbira na produção de textos escritos em português. In: BRAGGIO, S.L.B.; SOUZA FILHO, S.M. (Orgs.). Línguas e Culturas Macro-jê. Goiânia: Ed. Vieira, 2009. p. 25-41.

. Um panorama sobre a morfologia do Pykobjê. Guavira Letras, Três Lagoas, v. 8, p. 1-17, 2009.

, RODRIGUES, R. A flexão do verbo no português. In: LIMA-HERNANDES, M.

C.; CHUlatA, K. A. (Orgs.). Língua Portuguesa em foco ensino-aprendizagem, pesquisa e tradução. Lecce, Itália: Pensa, 2010. p. 45-71. 
ARAÚJO, L. Aspectos da língua gavião-jê. Tese (Doutoramento em Linguística) Universidade Federal do Rio de Janeiro, Rio de Janeiro, 1989.

ÁVILA, T. Unidade Timbira - cultura e etnias em um complexo social. 2005. Disponível em: http://www.trabalhoindigenista.org.br/papers.asp. Acesso em: 15.10.2010.

BACCILI , V.C.L. Reflexões sobre a influência da língua materna Kaingang no aprendizado do português como segunda língua. Dissertação (Mestrado em Letras) Universidade Estadual de Londrina, Londrina, 2008.

CAMARA Jr., Joaquim Mattoso. Estrutura da língua Portuguesa. 42. ed. Petrópolis: Vozes, 2009.

CASTILHO , A.T. (Org.) Gramática do português falado. Volume I: a ordem, Editora Unicamp, Campinas 2002.

Nova Gramática do português brasileiro. Contexto, São Paulo, 2010.

COMRIE, B. Aspect. Cambridge: Cambridge University Press, 1976.

CORDER, S. P. The significance of learners' errors. International Review of Applied Linguistics, v. 5, p. 161-9, 1967.

CUNHA, C. e CINTRA, L.F.L. Nova gramática do português contemporâneo. $3^{a}$ ed., Rio de Janeiro, Nova Fronteira, 2001.

FERREIRA NETTO, W. Linguística e educação indígena. $\mathbf{5 0}^{\circ}$ Seminário Gel, São Paulo, 2002. Disponível em http://www.fflch.usp.br/dlcv/lport/pdf/WFNetto01_EducInd01.pdf. Acesso em 25.07.2011. 
FERREIRA, M. N. O. Estudo morfossintático da língua Parkatêjê. Tese (Doutoramento em Linguística)- Universidade Estadual de Campinas, Campinas, 2003.

FILIPOVIC, R The Yugoslav Serbo-Croatian-English Contrastive Project : Theoretical and Methodological Considerationin Serbo-Croatian English Contrastive Grammar, Zagreb, Rudolf Filipovic ed., p. 9-36, 1985.

FONSECA, A. M. H.Tempo, Aspecto, Modo / Modalidade (TAM) na expressão de futuridade. Estudos Linguísticos, São Paulo, n. 39, v. 1, p. 45-58, 2010.

FRIES, C. Teaching and Learning English as a Foreign Language. Michigan, University of Michigan Press, Ann Arbor, 1945.

GARGALlO, I. S. Análisis Constrativo, Análisis de Errores e Interlengua en el marco de la Linguistica Contrastiva. Madrid, Editorial Síntesis, 1993.

KATAMBA, F. Morphology. New York, St. Martin's Press, 1993.

LADEIRA,M. E. Sobre a língua da alfabetização indígena. In: A questão da Educação Indígena. CPI-SP e Editora Brasiliense - São Paulo, 1981. Disponível em http://www.trabalhoindigenista.org.br/papers.asp Acesso em 06.04.2011.

A troca de nomes e a troca de cônjuges: uma contribuição ao estudo do parentesco Timbira. Dissertação (Mestrado em Antropologia) - FFLCH-USP, São Paulo. 1982.

Educação escolar indígena: projetando novos futuros. 1999. Disponível em: www.trabalhoindigenista.org.br/papers.asp. Acesso em: 15.10.2010. 
—. De bilhetes e diários: oralidade e escrita entre os Timbira. In: SILVA, Araci Lopes; FERREIRA, Mariana K. Leal (Orgs.) Antropologia, História e Educação. Fapesp/Mari/Global Ed: São Paulo, p.303-30, 2001

. De 'povos ágrafos' a 'cidadãos analfabetos': as concepções teóricas subjacentes às propostas educacionais. 2005.2 Disponível http://www.trabalhoindigenista.org.br/papers.asp. Acesso em 02.06.2011.

LADO, R. Linguistics across cultures. Michigan: University of Michigan, Press edition, 1957.

MATTOS e SILVA, R. V. “O português são dois”... Novas fronteiras, velhos problemas. São Paulo, Parábola, 2004.

MUSPRATT, S., LUKE, A. \& FREEBODY, P. Constructing critical literacies. Sydney, Allen \& Unwin; and Cresskills, NJ: Hampton.1997.

NIMUENDAJU, C. The Eastern Timbira: University of California. In: American Archaeology and Ethnology, Berkeley and Los Angeles, University of America Press, 1946.

. A corrida de toras entre os Timbira. MANA, v. 7, n. 2, p.151-194, 2001.

KUNTATH, S. P. O Aspecto Lexical na Aquisição dos Tempos Verbais do Passado em Português com Segunda Língua. Latin America Studies Association of Korea, v. 23, p. 65-88, 2004.

PIRES, G. S. Aquisição da morfologia verbal do português por um falante de Finlandês: o papel do Code Switching. Dissertação (Mestrado em Linguística Aplicada), Universidade Estadual de Campinas, Campinas, 1999. 
ROBISON, R. The Primacy of Aspect: Aspectual Marking in English Interlanguage. In: SSLA, n.12, p.315-330, 1995.

RODRIGUES, A. D. Línguas Brasileiras: Para O Conhecimento das Línguas Indígenas. v.1, São Paulo, Loyola, 1986

Macro-Jê. In: R. M. W. Dixon; Alexandra Y. Aikhenvald. (Org.). The

Amazonian languages, 1 ed, Cambridge, Cambridge University Press, p. 164-206, 1999.

SÁ, R. M. Análise fonológica preliminar do Pykobyê. Dissertação (mestrado em lingüística), São Paulo, Faculdade de Filosofia, Letras e Ciências Humanas, 1999.

SANTOS, L. A. Modos de escrever: tradição oral, letramento e segunda língua na educação escolar wajãpi. Tese (Doutoramento em Linguística Aplicada). Universidade Estadual de Campinas, Campinas, 2011.

SELINKER, L. Interlanguage. International Review of Applied Linguistics, v. 10, p. 209-241,1972.

SILVA, A. A expressão da futuridade no português falado. Araraquara, UNESP, FCL, Laboratório Editorial, São Paulo, Cultura Acadêmica Editora, 2002.

SOUZA, S.M. A sintaxe de uma língua de verbo no final: Krahô. Tese (Doutoramento em Semiótica e Linguística Geral) - Faculdade de Filosofia, Letras e Ciências Humanas, Universidade de São Paulo, São Paulo, 1997.

TRAVAGLIA, L. O aspecto verbal no português - a categoria e sua expressão. Uberlândia: Gráfica da UFU, 1981. 


\title{
ANEXO
}

\section{REDAÇÕES DIGITADAS}

\author{
Os textos abaixo são cópias fieis das redações timbiras e estão desprovidos de quaisquer \\ correções ou modificações.
}

Texto 1

1.Antigamente as tradições do povo Krahô, os mais velhos contam assim: Os krahôs dos antepassados 2.viviam nús, viajavam a pé, faziam muitas festas, não tinham lugares certos para morar, não tinham limites 3.do territórios, não tinham contatos diretos com as sociedades regionais e não usavam shorts.

4.Nos dias de hoje, muitas coisas mudou. Os jovens não viajam a pé, só espera o carro, não podem andar 5.nús, usar direto o short, quase não tem festa todo dia, vai direto a cidade próximo, precisa de todo 6.documento para viajar a grande cidade, quando tem a festa na aldeia só o velho participar, e o jovem fica 7.dentro da casa curtindo música, assistindo TV,etc. E assim por diante, as crianças que ainda estão 8.crescendo preceber...

9. As crianças que estão crescendos perceber e quando vão crescer, não acompanhar e respeita a tradição, 10.somente vai desvalorizar a cultura

\section{Texto 2}

1.Os meus povos brasileiros nos passado, eram muito forte para luta a guerra, eles se pintavam para 2.convence seu inimigo.

3.As populações indígenas Timbira, tivemos característica para caçar, pescar,pintar e plantar na roça.

4.Hoje em dia para nós, sabemos que a nossa tradição é forte, porque nos preservamos muito, nós corremos 5.com tora,cantamos no pátio, caçamos na mata, pescamos no rio, lagoa,ribeirão e córrego mais próximo da 6.aldeia.

7.O meu futuro, eu não vou deixa a minha tradição, nós sabemos que quaze toda indígenas estarão perdendo 8.os costumes do seu próprio povos. Nós que vivemos no norte do Estado, estamos comprendo e preservando 9. tudo que nossos povos krahô deixar

\section{Texto 3}

1.Antigamente o índio estarão a qui para discutir aqueles coisas está no passado e nós querem faze pra ter 2.mais alegria e ter grande animação da casa, porque na minha realidade eu nim pensei pra mim fazer uma 3.única coisa que é mais verdade [...] pra mim decora no meu pensamento.

4.A aula da qui foi muito importante pelos professora Rosane e eu gostei muito da aula dela e fiquei mais 5.feliz, hoje e a aprender sobre estudo. Coisa linda coisa no presente e que dizer que a final aula vai ajutaram 6.muita gente aqui na escola.

7.Vamos pensar desse o que vai acontecer nesse animação da festa aqui na escola indígena timbira temos 8.vario discussão a gente fazer aqui queremos explicar que dia mais [...] ou periodo que vai ter grande 9.animação dos alunos.

\section{Texto 4}

1.No ano de 1989 tinha muitas festas e não cortam cabelo como hoje que os homens,cortarão mais os mais 2.velhos gostava de ir para a cidade que eles não tinha nada como nós temos um pouco.

3.Porque só ce acaba com a nossas cultura que os meus bisavós nós usar, que na minha você não ver os 4.jovens cortando os cabelos como os cupê cortam os cabelos ne as mulheres não gria os cabelos as cupê. 5.Já tem os nossos jeito de viver que antigamente não tinha nada de cupê e não. Mas agora nós que ficam na 6.aldeia nós não temos mais resguarda como os mais velhos tinha, agora nós comem as coisas que os cupê 7.comem 
8.Mais agora nos estamos ensinando as crianças cantar que eles estão aprendendo que eles não tem mais 9.vergonha de canta e eles não cortão os cabelos como que os aluno que os cabelos como os cupe que eles se 10. amostra como qui.

\section{Texto 5}

1.Antes era todos das tradições da antigamente, nos vivemos pela tradição indígena que para conhece os 2.costumes de outros, bem diferente.

3.E não tem que você índio vai se acabar a sua tradição. Eu conheço. A minha tradição a minha propria 4.palavra. E com os outros que e parecida e que e mas a mesma tradição ou mas do passado. Mas gostam da 5.minha tradicionaes culturais e constume.

6.Mas eu não vou largar vou sempre ficar perto porque e disso que a pessoa vivem em seus lugar

\section{Texto 6}

1.No passado nós passamos uma vida muito melhor antes dos Português chegada aqui.

2.E depois de 1900, começaram consequencia muito rara de contato, mais conflitos em ocupação de recursos 3.naturais.

\section{PRESENTES}

5.Ainda nós tem nossa cultura e preservando e aprendendo com os mais velhos que conta a história ontesico. 6.No que aprendeu com outro velhos.Temo 3002 mil hectásios de terra objetivo e preservar a naturizas.Tem 7.programa de saúde e educação e outas órgão governamentais.

8.FUTURO

9.Espero uma vida melhor para o meu povo. Para que seja de sucesso e paz e alegria. Não esquecem do 10.nosso modo de viver e reconhecido no iniverso com diversas contribuições físicas tais e profissional 11.entender os dois mundo

\section{Texto 7}

1.Os antigamentes os índios que viviam na terra eles sempre vinha mantendo a sua própria tradições mesmo. 2.Cantar no pátio correr com tora, caçar no mato, trabalhar nas roças enfim a nossa tradição era muito boa 3.antigamente todos dos dias ele ela pintar para a festa que faz nas aldeias. A gente usava genipapo para 4.pintar o corpo, também urucum para pintar igual o genipapo nós usava também pau de leitepara pintar também.

5.Em dia de hoje a nossa tradição indígena esta sendo extinto que tem muito jovens que está deixando de 6.utilizar a sua propria tradição indígena que venha sendo feito no passado. Mas na minha aldeia não tem 7.isso, sempre temos a nossa tradição propria mesmo mas tem vares aldeia que só estão perdendo a sua 8.tradição.

9.Mas eu penso no futuro eu não vou deixar meu povo perder a sua tradição

\section{Texto 8}

1.Povo krahô do antigamente fazer uma tradições a sim. tradições do povo krahô do antigamente fazer uma 2.corrida. E a pessoas ele vai cortar um tora. E a tarde de 3 jora e já ta na hora de corrida. Povo krahô do 3.antigamente todos mundo ele vai pum torrci. Em a noite e as pessoas ele vai chegandos e todo mundo vai 4.cantar. Agora vai terminar até amanha cedo. Em tem vários tradições povo krahô.

\section{Texto 9}

1.Antes meus povos eram muitos animados faziam tudo que eles quizerem fazer, cantava todas as noites 2.corriam todos os dias, fazem as festas todos os dias. Todos pintados e todos os cabelos cortados...

3.Mas hoje em dia os novos não faz assim como era ante. Hoje os novos não faz as festas todos os dias, faz 4.as festas de vez em quando, não cortar cabelo não pinta, não corre todos os dias corre de vez em quando ou 5.corre só no dia de festa...

6.Eu acho que no futuro filho não vai pegar esse tradição que nosso bissavô deixou para a gente.porque 7.ninguem vai querer cortar cabelo e pintar o corpo com jenipapo e urucu. Eu estou pensando assim 
Texto 10

1.Lá na minha aldeia, eu corro todo dia bem cedo nunca eu vou deixar a minha tradição, sempre eu vou usar 2.a minha tradição e costume.

3.No futuro a criança não quero saber de correr com a tora e nem fazer festa na sua aldeia quer vira com 4.cupê. Porque nos já alimentamos a comida do branco só por isso, os mais velhos briga com a gente para 5.não virá com branco.

6.Os antigamente os velhos índios não usava roupa anda pelada nem vestir só faz a sua festa na aldeia corre 7.todo o dia, e casça e pesca e sempre está usando tradição mas forte ainda.

\section{Texto 11}

1.Sim Antigamente os índios velhos que não tem lugar certos para mora na aldeia.

2.Mais desqui e nós vivemos lá no fim do céu azul os outros velhos disse sempre estamos ouvindo.

3.Mas premeiro os índios gostavam de muita festa para fica algre para corre mas premeiro. A gente vai 4.pintar com jenipapo e pau - de -leite e urucum. Quando vai para corre vai ser muito sol quente da atarde 5.mas sempre corre embaixo.

6.Mais agora nesses dia nesses anos de 2006 já ta quais índios não lembrou os costumes quando os 7.comunidade vamos fazer outros festa os juventude não ajudar de corre. Vai só olhar porque.

8.Eles não aprendio de corre so por isso não quer hojé dia tan só abasando cabelos e usam camisete para 9.anda trânsqueiro

\section{Texto 12}

1.Antigamente, as tradições do meu povo eram são mais avançada. Por que, quando eles vão iniciar alguns 2.festa, todo mundo vão ser pintado o corpo de qualquer jeito. Mas para pintar o corpo tem que ter jenipapo, 3.pau- de - leite ou urucum. E na verdade no passado o meu povo finalizem a festa com dansse da caças. 4.Atualmente hoje, sempre nós continua de relembrar-se a nossa tradições. Porque se não mostra para nós? 5.Então agente esquece, por isso sempre o meu povo continua de mostrar a tradições da nossa tribos. Mas 6.neste momento agente não pega a regra do passado.Agora nós estamos fazendo com diferente.

7.Na verdade, os novos que vão estarei no tempo vão passando cada vez mais. Vão aprender tudo que agente 8.fazem no presente ou no passado. Porque eles não vam corre, dacar,trabalhar com roça. Eles estão correndo 9.só atrás do cupê

\section{Texto 13}

1.Eu conto muito tradições dos antigamentes, porque naquela época eram preservado a cultura. E mesmo 2.assim que nós lembrando da nossa ritual. E até hoje nós joventude nunca vai esquecer a nossa cultura. E 3.até agora sempre que os velhos vai discutir no pátio ou no pensão. E fazer aquela festa e nós joventude vai 4.acompanhar, de corrida, dança no pátio. E nunca vão esquecer a nossa cultura.

5.E eu penso assim, eu acho criança que vem em depois, vai peder a nossa cultura. Porque já estavam usando 6.a camisa e short.

Texto 14

1.Antigamente, os povos indígena fazer a festa e todos pintarão no corpo com jenipapo e urucu passa no 2.corpo também E fazendo também chapel de folha de burite, coloca no pescoço também.

3.Só duas pessoa cortam a tora lá longir e povos só esperando eles quando chegarão o povos todos vai atras 4.de tora para pegar eles, voltam para aldeia.

5.Corridas de mulheres, homens, criança todos correndo com tora. Ne um ficando parado todos companhado 6.a tora.

7.Mas é cada partido tem inverno e verão qual partido ganhar com tora.

\section{Texto 15}

1.Eu vou fazer a redação sobre futuro, no meu pensamento que eu penso no futuro, como eu estou estudando 2.de português e matemática, ciência, geografia, e quando eu aprender de todos matérias que eu estudo na 3.escola, e depois eu começo ganha um emprego para trabalhar com próprio mehi, na aldeia cachoeira e para 
4.devende meu povo.Só isso que eu estou pensando no meu pensamento de futuro. Porque os branco que 5.trabalha na aldeia que fica só brincando e só faz o projeto para as comunidade da aldeia, só por isso que 6.índio não que mas cupê trabalha na aléia, só índio que mais gosta de trabalha.

7.A da futuro nós são tribo krahõ não dexa nosso futuro, sempre nós representa nosso futuro.

Texto 16

1.Antigamente não tinha nada e os mahi andava nas aldeias, fazendo a festa todo dia, e anoite a gente cantar 2.com o maracá.

3.Só pensando de correr de amanhã bem cedo, não lembram a cidade só lembram a cidade só lembram a 4.aldeia e casada.

5.Antigamente só veve na aldeia, correndo com a tora de buriti. Só cuidar as famílias nas aldeias.

6.Mas hoje em dia os índios já aprendemos a cultura do cupê. Antigamente eu sou era nada, não percebendo

7.o que já repaçou. Antigamente os mais antigo saber tudo no século passado.

8.Não perco nosso instrumento nosso bisavô deixou.

Texto 17

1.Antigamente eram o tradição foi bem feitos, a gente pintavam o corpo, cortavam cabelo e faz a brincadeira 2.para agente almar, na hora da festa dos índios ninguém vestir roupa.

3.Todo mundo pintam co jinipapo, pau - de - leite e depois pintar com urucu, a gente faz chapéu de imbira.

4.E na hora de correr com a tora o chamador chama agente para juntar e correr, a tora fica no mato que 5.agente vai buscar e até chegar na aldeia.

6.A noite começar a cantar com maracá para as mulheres a companha aquele contador, mas tem muito 7.barulho de instrumento de busina,cabacinho e etc.

8. Essa que os tradição dos índios Krahô, não esqueça a nossos tradição.

Texto 18

1.Antigamente o índio que cantar todos os dias noite, cem para noite. Porque? Tem muitos cantor.

2.Hoje me dia cantora não vai cantar no pátio mas agora, em dia noites porque?

3.Cantar mas difícil cantar no pátio.

4.Hoje? Em dia não vai cantano no pátio porque?

5.Cantar mas difícil para festar. Hoje, para nós mas sim.

\section{Texto 19}

1.Na antigamente nós tradição era vive e era muitos a diferenciadas só os índios velhos usam os seus 2.costumes para não esquecer suas tradições sempre usava seus tradições.

3.Até agora os índios novos nunca esquecer as tradiçõe que os abisavós deixara para os filhos e netos.

4.Quando e antes de esquecer as tradição dos índios velhos

5.- Eles dizem para suas filhos e para outras pessoas que vivem na mesma aldeia.

6.Dizem assim meus filhos e meus parentes não vão perder a nossa cultura e as tradição, vamos relembrar do 7.nosso passado, que é nossa cultura ainda ta viver. Vamos cuidar da nosso costumes.

8.Até hoje os costumes, tradição, contoria, corrida, armas de flecha não ainda foi deixados. Por que a nossos 9.bisavós deixou para nós índios. Porque cada esses costumes tem suas próprias histórias, para relembrar os 10.passados tudo foi deixados para próximos filhos usarem e pensar no futuro o que ta possindo para chegar. 11.Que o mundo não tem fim. Até agora nós sempre relembrando os passados, nunca nós deixamos as 12.tradições dos kraolandios.

\section{Texto 20}

1.Antigamente os índios tinham tradição conservada, os povos fazem suas festas com muitos alegrias e 2.também ante suas florestas eram ricas de caças, pescas,flora,paisagem naturais etc.

3.Hoje me dia nós jovens conservamos essa tradição com bastante carinho, sempre nós fazemos festas para 4.poder lembrar a tradição do nosso bisavô.

5.Os futuros netos vão segurar os costumes e mantendo conservar a nossa língua, tradição, o jeito de viver, etc 
Texto 21

1.Os povos Apãnjekrá premeiramente os velhos andavam nús, em culturamente deles, nas festas que tivemos 2.no tempo dos índios velhos em anjikim, torão, festa de peixe e ainda mais outras festa.

3.Agora os jovens já não usava aquela tradição que os velhos usavam premeiramente na cultura, mas 4.realmente a cultura continuava mesma em passado que os velhos faziam festa, correr a tora,prissão, batata, 5.gavião, pikahhoc, esta anjiki ainda existe todos em nossa cultura canela.

Texto 22

1.Antigamente os velhos cantavão no pátio alguma coisa ou história ai os jovens ter que participar no pátio 2.todo mundo josveis os velhos também

3.Quando velho manda todos nós nós companha aquele nosso leias as mulheres companha também porque 4.nosso leia e diferente nem tal igual com bancos não ai nós fazer alguns brincadeira nas aldeia ou 5.brincadeira de laranja ou brincadeira de peixe nós brinca até a noite inteiro ou até de amanhã termina seis 6.hora da amanhã. E também outros historio passado que os velhos contavos nos pátio para todos jovens . Eu 7.também participar todo dia.

8.Hoje eu fui para aldeias trabalharemos bastantes voltareis a tardes. Eu fui tomar banho ló nos rios voltareis 9.para casas a tardes .Eu fui goigas bolas la nos campos.

\section{Texto 23}

1.Os índio cantaram todos os índio no pátio ainda no futuro ainda Hoje a noite nós todos cantaram no pátio. 2.No passado a gente correu todos mundo correu. As pessoas da minha aldeia gostam de pintar o corpo . No 3.pátio os jovens aprenderam as histórias de antigamentes.

4.Os mais velhos se reuniram no pátio para discutir algumas questões na semana passada.

5.Nas festas, nós cortamos o cabelo pintamos o corpo e corremos com tora.

6.No presente ainda existem atradiçõs de índios. A gente pintamos todos mundo no pátio cantando todos 7.juntos ainda hoje existem atradições.

\section{Texto 24}

1.No antigamente que Ijõ jajá comta esta história, primeiro, os índios anda em nu, com folha patras e 2.prafrente.

3.Os índios se alimentam em pau podri no antigamente, eles em vivem assim, anda mas eles se pinta, urucu, 4.paudi leite.

5.Também índios não esquece os usu deles nas festa, eles comes umas coisa só.

6.Mas hoje o índios não eram assim agoras, o índio se vivem milhor com arroz, farinha,carne, e tem vares 7.outras coisas para se viver hoje.

8.O índio anda bem prontos com roupas bem prontos, calção, camisa e também nós índios falamos com cupê 9.meio milho.

10.São muito importante porque , nós índios esta acontecendo em cada aldeia de nós e eu não sei as outras. 11.Tem deles que estavam acabando o cultura des em próprio aldeia, com nem forca para propria aldeia, 12.como nem forca para propria comunidade

Texto 25

1.Antigamente vou conta a história para vocês os mais velhos juntarão pátio e conbinariam como que a festa 2.começa o primero ou a festa de witi ou de laranja. Aí a gente vão fazer a festa todo mundo pintarão com 3.pau de leite ou de jenipapo outro pintam com urucu vão para a onteque a tora fica que outra pessoas 4.contaram para homem mulheres.Quando nós corremos depois a noite também as mulheres cantarão os 5.homens fica na frente das mulheres.

6.Mas hoje sempre os homens juntamos no pátio conbinavam a fazer a festa mais os jovens não escutavam a 7.comunidade o que as comunidade estão fazendo. Por isso pore enquando a gente não escutavam e nem 8.respeitando outro não e pintar e nem cantam os mais velhos falaram por novos da conselho por moça, 
9.jovens porque as moças não cantavam sabe nada o cantiga o que quer os mais velhos cantam. Mas sempre 10.os mais novo esta fazendo a festa e da cultura

Texto 26

1.Bom antigamente a nosso tradições bem organizada, pelos mais velhos, o cantor, e cacique, governadores, 2.são mandado pelo festa de qualquer tipo festa de tradições, costumes, corrida de tora. Todos mundo vão 3.participa festa, tora pra ter alegrea do povos, as crianças, adulto,muleres, e homen, mas a tora que mais dá 4.alegria para todos comunidade no krî é chama parti é uma tora de batatas, que todos, adultos homem e 5.crianças deve ter paparuto, Pra comer lá no pátio, e dicudir que todos ganhar iguais, as adultos crianças 6.depois leva pra casa e a mulher também vai comer .

7.Então esse tipo festa de torão, tem dentro paparuto, são misturado. Então a gente preserva ainda muitos 8.mimos. Olha nós somos povos Ananjekra faz festa bem organizada. Hoje em dia tantos antigamentos, tanto

9.faz em 2006, usa nosso tradições fortes.

\section{Texto 27}

1.Quando meu povo gavião fazer uma festa todos homens vai para a corrida de tora mas os velhos que vai 2.cortar essa tora eles fala para os jovens olha já que vocês comessaria a cultura de nossu bijavo nós 3.cantamos principais musicas.

4.Eu venho canta com todo que aparesen na verdade com as mulheres por que elas tira a fruta que a terra dar 5.para todos nós índio temos genipapo urucu e sua artesanato para enfeitar o corpo.

6.O povo da aldeia governador fazer a sua caçada pelo aquilo que nossa bijavo fazia antigamente pela mata. 7.Eles matavam muitas caça na verdade quando todos ssai pra a sua aldeia só uma pessoa vai canta para as 8.mulheres

\section{Texto 28}

1.Antigamente o meu povo canta no pátio a noite inteiro para que eles não esquecer da cultura tradicional 2.que os mas velhos encinaram para eles, e quando começa a festa tradicional todos vão para o patio.

3.Hojé os mas jovens não faz mas as festa tradicional porque nem todos vam para o pátio, mas os mas velhos 4.vam para o pátio e eles já se proucupa com os jovens.

5.Os velhos contador se preocupa muito porque se eles morrerem os jovens vão perder os costume 6.tradicional porque eles não vão para o pátio não que aprender, os costume cultura e rituais, deles. Por isso 7.que os velhos se preocupa com os jovem hoje

\section{Texto 29}

1.Tradição passado até, Porque nós seguindo nossa tradições antiga que os mais velho tem para repassa para 2.os mais novo, té conhecimento rituais passado.

3.Preservamos a nossa tradição para ser o futuro do que ainda vai crescer, pensamos isso.

4.Os mais velhos, mostram tudo que sabe para os mais novos aprender e preserva as nossas cultura, pintura, 5.correr então até agora nós temos a nossa tradição preservada.

6.Brincadeira a corrida de tora de flecha cantamos tudo isso é nosso tradição preservada.

7.Nós povos brasileiro temos tradição preservada

\section{Texto 30}

1.Eu vou contar uma história que meu avô contou para mim, como era a vida deles no passado.

2.Bom a vida do meu povo era tranqüilo, eles caçavam, pescavam e levavam uma vida boa.

3.Antigamente, quando não tinha cupê, tinham muitas caças, peixes, frutas terra fértil. A cultura era muito 4.mais forte as nossas línguas, os costumes, as cantigas, músicas, festas, comidas e outros.

5.Hoje, atualmente tudo está diferente para nós. Com a chegada de homem branco, as caças acabaram, tem 6.caças mas poucos, as frutas estão poucas, peixe, madeiras para fazer casas.

7.E a cultura nossa está comprometida por causa de energia, gravador, rádio, roupa, dinheiro, comidas do 8.cupê e muitos costumes de cupê que é praticada na aldeia como futebol e etc.

9.No futuro não sei o que vai ser de nós se vai ficar bom para nós ou não.

10.Espero que nós os jovens de todas as etnias lutem pelos nossos direitos, assim teremos uma vida boa 11.tranqüila para nossas crianças e netos 
Texto 31

1.Nós contamos dos antigos como eram os índios, usava cola, pulseira e outro para eles fica efeitado. 2.Correram vários a volta, em torno da aldeia até também, usavam cabasinha, flantar, maracá, e outros 3.instrumento para o uso. Até que eles ficaram assim continuando a mesma.

4.Bom como sempre eu gosto muito da cantiga corre com tora, mass de $50 \mathrm{kl}$ ou mais. O nosso gostume é 5.muito importante, mulheres, homem tem dias para corre com a tora crianças também corre cantar também 6.na aldeia ou no pátio.

7.Hoje agente corre com toras a partide agora nós nunca esquecemos a nossa cultura. Que faz felicidade para 8.agente e se alegra e divertir juntos com meus grupo.

\section{Texto 32}

A realidade do Indio

1.Antigamente os índios deste primeira década dos anos anteriores, não existia os brancos nessa terra, existia 2.so índio, e naquela época os índios tem própria sua cultura, eles andavam nu pintado com tinta de jenipapo, 3.urucum com colares bonitos com sua cultura rica.

4.Mas 1.400 anos atras começou contatos e massacre com índios aqui no Brasil que não existia esse nome 5.ainda, e como eram antigamente os brancos acroaticamente alienável acomodadamente com os índios eles 6.fizeram revolução política e os índios modificou a realidade na media estrutura, uma parte pouca civilizado 7.e uma boa parte existe propria será sua cultura ainda.

8.Mas eu fico preocupado sempre, porque as vezes daqui a 100 anos pra frente todos índios vai virar brancos 9.e não vai mais existir índio puro, mas hoje por enquanto existe propria cultura ainda, e nós que somos 10.índios, eu sempre ouvi alguns índios falar que está preocupado com a cultura para agente não perder 11.nossa cultura.

\section{Texto 33}

1.História da aldeia Escalvada, que mais contato pela através dos velhos e antigamente.

2.Na época foram grande com tradições de festa e cultura indígena, quém é descobrir para a situação o povo 3.falar do awkê, história do abisavos que ficou no tempo e anos atrás.

4.Quando eu lembrei dos antes, estava aconteceram e lugares, aldeia os velhos fez reunião a todo 5.comunidade acordo de acaba e matou awkê.

6.Capacitação da festa e pintando de mulheres e homem jovem, agora mais diferente do mehĩ

\section{Texto 34}

1.Bom, antigamente tradições eram muito bom, todo mundo pinta de urucu pau-de-leite cortar cabelo e quais 2.todo mundo fura as orelhas, mais ao menos 30 pessoas, e quais todo mundo canta, mais ou menos 60 3.pessoas que cantam. Mas só tinha 6 cantores profissional que canta no pátio com maracá para as mulheres. 4.Mas hoje, como somos novo, não são todos que sabe cantar, são poucos, mais de 10 pessoas. Tem ainda 30 5.cantores profissionais que canta, 2 canta de maracá no pátio, 1 canta na casa de wy ty que é Rainha. Hoje 6.poucos que usa a pintura, não é todo mundo, pouco corta cabelo, pouco fura orelha e pouco são corredor, 7.mas nós ainda estamos usando as tradições.

8.Mas nesse ano 2006 pra 2007, fizemos novo plano pra nós não perder as tradições cultura e festas que está 9.acontecedo.

10.Nós preservamos e seguramos para eles usarem para frente

\section{Texto 35}

1.Antigamente na minha aldeia tinha o conto indígena, tinha corrida de tora a corrida flecha e tinham as 2.pintura para o corpo e também festa dos povos para pode, ou corrida de faze ou cantadores. Até tinha pena 3.de pasaro [...] pintura e também tinha festa dos pexe faz paparuta angente canta até de manhã agente vai 4.destribui o que que vam comer de manhã é paparuta.

5.Agora outra coisas os mais velhos contar então quando você namora com qualqué as menina se pura-causa 6.se você corredo você vai ne dorme na casa você dorme no pátio com folha de sucupira pra poder mais forte 
7.e sente ne cusono.

Texto 36

1.A tradições do povo apinajé no passado os mas velhos contam que a cultura era mais valorizada fasiam 2.varias festas cultural, festa de caçada, festa de peixe, festa de tora, festa de batata, festa de milho, festa de 3.pintura, etc...

4.foi assim que os mais velhos contam do passado.

5.Nós apínajé estamos deixando de fazer algumas festa mas estamos recordando tudo denovo esas festa para 6.os mas novos que tão crescendo. O povo apinajé sempre estão preservando a cultura nunca vamos deixa de 7.ser índio sempre vamos preserva a nossa cultura no futuro e recorda o passado para os joveis.

\section{Texto 37}

1.No antigamente os índios faziam suas tradição de viver, e fazer suas culturas, no passado os índios 2.gostavam muito de usar muitas tentais, de jenipapo para usar no seu corpo para ficar bonitas. para usar 3.também o urucu no corpo.

4.para ficar vermelho. para dança na festa de mehẽ, e para correr com a tora no passado os índios gostavam 5.muito de pintar com as tintas de jenipapo e com urucu para não esquecer das suas festas e da sua tradição 6.de viver com seus gostumins

\section{Texto 38}

1.Antigamente na minha aldeia tinham os costumes dos cantos, cantorias indígenas, tinham a corrida de tora, 2.a corrida de flecha e tinham as pinturas corporais, as festas dos presos, faziam artesanato, arco e flecha, 3.faziam colares e saiotas isso era antigamente.

4.Hoje na minha aldeia nós já perdemos quase todas essas tradições. Tudo isso por causa do contato com os 5.não índios. Hoje nós só corremos com tora e praticamos muito a pintura corporal e fazemos ainda arco e 6.flecha fazemos alguns colares e algumas saiotas.

7.Só que nós estamos fazendo a corrida de tora, a corrida de flecha, a pintura corporal porque se nós não 8.praticarmos mais iremos perder de vez todas essas tradições, estamos tentando trazer de volta as nossas 9.tradições para a nossa aldeia. Porque mais tarde todos irão perder mesmo e nós iremos sempre praticar.

10. Nós estamos com um projeto para trazer de volta as músicas tradicionais.

\section{Texto 39}

1.As tradições do meu povo no passado é muito bom: porque homem e mulher corre com a tora quando 2.chegar na aldeia começa a canta esse é nosso tradição e ritual que a gente tem na aldeia. O povo trabalha de 3.grupo na roça para ter muito alimento.

4.E no presente o meu povo não trabalha mas em grupo, cada um trabalha para ter de alimentação e também 5.cuida da família de casa. Quando o povo canta no pátio as moça e rapaz não chega para canta alguns 6.cantos, o povo não dá valor por nossa tradições.

\section{Texto 40}

1.Antigamente os mais velhos, cantarão todos dia no pátio, e correm com tora de manhã e a tarde. Porque 2.antigamente as tradições é muito valorizada, que a te hoje nós nunca vamos esquecer a nossa cultura.

3.Mas quem sabem as crianças que vem nascendo eles poço esquecer a nossa tradição Até agora a gente já 4.esquecerão muio cantiga, que os velhos, cantarão a noite no pátio.

5.Mais agora tem alguma que canta a nossa cantiga.

6.E com certeza que vai acabar a cultura do índio. Porque já tem muita gente que já perderão própo tradição 7.deles. E eu ficar com preocupado. 


\section{APÊNDICE}

\section{DIVISÃO E CLASSIFICAÇÃO DOS ERROS DAS REDAÇÕES}

Conforme o modelo de Análise de Erros, para a realização deste apêndice houve a identificação dos erros, a sua classificação, a determinação estatística da ocorrência dos mesmos e a identificação das áreas de dificuldades dos estudantes.

Das quarenta redações apresentadas no anexo 1, identificamos os desvios e estratégias de aprendizado abaixo selecionadas. Privilegiamos os desvios que apareceram repetidas vezes e que foram passíveis de análise lingüística, desta forma destacamos que a presente dissertação não destaca a completude das dificuldades de referencia ao tempo verbal de L2 por falantes de língua timbira, mas sim é uma tentativa de sistematização das áreas de dificuldades mais nítidas apresentadas nas redações.

A percentagem apresentada em cada quadro mostrado ao longo deste estudo, mais especificamente no capítulo 3, está baseada no total das quarenta redações englobadas pelo corpus e os exemplos selecionados compreendem os erros que obtiveram maior destaque nas discrepâncias com a norma padrão de L2. Assim, puderam ser selecionados diferentes erros em uma mesma redação, bem como erros similares em elaborações diferentes.

Ainda, destacamos que nas orações classificadas como exemplos nos quadros mostrados pôde ocorrer mais de um desvio da norma padrão do português. Entretanto, privilegiamos para a análise, somente as construções marcadas em negrito, por se tratar de uma tentativa de sistematização dos erros e das construções similares.

\begin{tabular}{|l|}
\hline 1- SUBSTITUIÇÃO DO PRETÉRITO IMPERFEITO PELO PRESENTE DO INDICATIVO \\
\hline ...e não cortam cabelo como hoje... \\
\hline Antes era todos das tradições da antigamente, nos vivemos pela tradição indígena \\
\hline cantava todas as noites corriam todos os dias, fazem as festas todos os dias \\
\hline as tradições do meu povo eram são mais avançadan \\
\hline $\begin{array}{l}\text { Só pensando de correr de amanhã bem cedo, não lembram a cidade só lembram a cidade só lembram a } \\
\text { aldeia e casada. }\end{array}$ \\
\hline Antigamente eu sou era nada, não percebendo o que já repaçou \\
\hline os povos fazem suas festas com muitos alegrias \\
\hline tradições do meu povo eram são mais avançada \\
\hline As pessoas da minha aldeia gostam de pintar o corpo \\
\hline outro pintam com urucu vão para a onteque a tora fica que outra pessoas contaram para homem mulheres \\
\hline Quando nós corremos depois a noite \\
\hline Os homens fica na frente das mulheres. \\
\hline naquela época os índios tem própria sua cultura \\
\hline faz paparuta angente canta de manhã agente vai distribui o que que vam comer de manhã é paparuta. \\
\hline
\end{tabular}




\begin{tabular}{|l|}
\hline As tradições do meu povo no passado é muito bom \\
\hline e correm com tora de manhã e a tarde \\
\hline Porque antigamente as tradições é muito valorizada \\
\hline
\end{tabular}

\begin{tabular}{|l|}
\hline 2- USO INADEQUADO DO INFINITIVO \\
\hline $\begin{array}{l}\text { Cantar no pátio correr com tora, caçar no mato, trabalhar nas roças enfim a nossa tradição era muito } \\
\text { boa... }\end{array}$ \\
\hline todos dos dias ele ela pintar para a festa que faz nas aldeias... \\
\hline Povo krahô do antigamente fazer uma tradições a sim... \\
\hline tradições do povo krahô do antigamente fazer uma corrida... \\
\hline Antigamente, os povos indígena fazer a festa... \\
\hline Mas é cada partido tem inverno e verão qual partido ganhar com tora... \\
\hline só cuidar as famílias nas aldeias... \\
\hline a gente pintavam o corpo, cortavam cabelo e faz a brincadeira para agente almar... \\
\hline Todo mundo pintam co jinipapo, pau - de - leite e depois pintar com urucu... \\
\hline A noite começar a cantar com maracá... \\
\hline em passado que os velhos faziam festa, correr a tora,prissão, batata, gavião... \\
\hline Eu também participar todo dia... \\
\hline No antigamente os índios faziam suas tradição de viver, e fazer suas culturas... \\
\hline
\end{tabular}

\begin{tabular}{|l|}
\hline 3- SUBSTITUIÇÃO DAS FORMAS DO PRETÉRITO IMPERFEITO PELO PERFEITO \\
\hline Antigamente eram o tradição foi bem feitos \\
\hline nas festas que tivemos no tempo dos índios velhos em anjikim \\
\hline No passado a gente correu todos mundo correu \\
\hline No pátio os jovens aprenderam as histórias de antigamentes \\
\hline Quando nós corremos depois a noite \\
\hline Correram vários a volta, em torno da aldeia \\
\hline Na época foram grande com tradições de festa e cultura indígena \\
\hline
\end{tabular}

\begin{tabular}{|l|}
\hline 4- SUBSTITUIÇÃO DO PASSADO PELO FUTURO \\
\hline E a pessoas ele vai cortar um tora... \\
\hline Em a noite e as pessoas ele vai chegandos e todo mundo vai cantar... \\
\hline Por que, quando eles vão iniciar alguns festa, todo mundo vão ser pintado o corpo de qualquer jeito.... \\
\hline Aí a gente vão fazer a festa todo mundo pintarão com pau de leite... \\
\hline de manhã agente vai destribui o que que vam comer... \\
\hline
\end{tabular}

\begin{tabular}{|l|}
\hline 5- USO DE ADVÉRBIOS COMO AUXILIARES PARA MARCAÇÃO DO TEMPO EM INÍCIO DE \\
TÓPICO \\
\hline Antigamente as tradições do povo Krahô.... \\
\hline No ano de 1989 tinha muitas festas.. \\
\hline Antes era todos das tradições da antigamente.... \\
\hline No passado nós passamos uma vida muito melhor antes dos Português chegada aqui... \\
\hline Os antigamentes os índios que viviam na terra.. \\
\hline Povo krahô do antigamente fazer uma tradições a sim... \\
\hline Antes meus povos eram muitos animados... \\
\hline Os antigamente os velhos índios não usava roupa... \\
\hline Sim Antigamente os índios velhos que não tem lugar certos para mora na aldeia... \\
\hline Antigamente, as tradições do meu povo eram são mais avançada... \\
\hline ...naquela época eram preservado a cultura... \\
\hline
\end{tabular}




\begin{tabular}{|l|}
\hline Antigamente, os povos indígena fazer a festa.. \\
\hline Antigamente não tinha nada e os mahi andava nas aldeias.. \\
\hline Antigamente eram o tradição foi bem feitos... \\
\hline Antigamente o índio que cantar todos os dias noite... \\
\hline Na antigamente nós tradição era vive e era... \\
\hline Antigamente os índios tinham tradição conservada... \\
\hline Antigamente os velhos cantavão no pátio alguma coisa ou história... \\
\hline No passado a gente correu todos mundo correu... \\
\hline No antigamente que Ijõ jajá comta esta história... \\
\hline Antigamente vou conta a história para vocês... \\
\hline Antigamente os índios deste primeira década dos anos anteriores... \\
\hline Mas 1.400 anos atras começou contatos e massacre com índios aqui no Brasil... \\
\hline Na época foram grande com tradições de festa e cultura indígena... \\
\hline antigamente tradições eram muito bom... \\
\hline Antigamente na minha aldeia tinha o conto indígena... \\
\hline No antigamente os índios faziam suas tradição de viver.... \\
\hline Antigamente na minha aldeia tinham os costumes dos cantos... \\
\hline Antigamente os mais velhos, cantarão todos dia no pátio... \\
\hline
\end{tabular}

6- USO DA MEMÓRIA COLETIVA

os mais velhos contam assim...

Eu conto muito tradições dos antigamentes

E também outros historio passado que os velhos contavos nos pátio para todos jovens

Ijõ jajá comta esta história

Eu vou contar uma história que meu avô contou para mim

Nós contamos dos antigos como eram os índios

História da aldeia Escalvada, que mais contato pela através dos velhos e antigamente

A tradições do povo apinajé no passado os mas velhos contam

\section{7- USO DO PRESENTE HISTÓRICO}

Quando velho manda todos nós nós companha aquele nosso leias as mulheres companha também porque nosso leia e diferente nem tal igual com bancos não ai nós fazer alguns brincadeira nas aldeia ou brincadeira de laranja ou brincadeira de peixe nós brinca até a noite inteiro ou até de amanhã. primeiro, os índios anda em nu, com folha patras e prafrente.

Os índios se alimentam em pau padre no antigamente, eles vivem assim, anda mas eles se pinta, urucu, paudi leite.

Também índios não esquece os usu deles nas festa, eles comes umas coisa só.

são mandado pelo festa de qualquer tipo festa de tradições, costumes, corrida de tora. Todos mundo vão participa festa, tora pra ter alegrea do povos, as crianças, adulto,muleres, e homen, mas a tora que mais dá alegria para todos comunidade no krî é chama parti é uma tora de batatas, que todos, adultos homem e crianças deve ter paparuto, Pra comer lá no pátio, e dicudir que todos ganhar iguais, as adultos crianças depois leva pra casa e a mulher também vai comer .

Antigamente o meu povo canta no pátio a noite inteiro para que eles não esquecer da cultura tradicional que os mas velhos encinavam para eles, e quando começa a festa tradicional todos vão para o patio.

todo mundo pinta de urucu pau-de-leite cortar cabelo e quais todo mundo fura as orelhas, mais ao menos 30 pessoas, e quais todo mundo canta, mais ou menos 60 pessoas que cantam. Mas só tinha 6 cantores profissional que canta no pátio com maracá para as mulheres.

porque homem e mulher corre com a tora quando chegar na aldeia começa a canta esse é nosso tradição e ritual que a gente tem na aldeia. $\mathrm{O}$ povo trabalha de grupo na roça para ter muito alimento

Os antigamente os velhos índios não usava roupa anda pelada nem vestir só faz a sua festa na aldeia corre todo o dia, e casça e pesca e sempre está usando tradição mas forte ainda.

\section{8-SUBSTITUIÇÃO DO PRESENTE PELO INFINITIVO}




\begin{tabular}{|l|}
\hline ...quando tem a festa na aldeia só o velho participar, e o jovem fica dentro da casa curtindo música... \\
\hline $\begin{array}{l}\text { Porque só ce acaba com a nossas cultura que os meus bisavós nós usar, que na minha você não ver os jovens } \\
\text { cortando os cabelos como os cupê cortam }\end{array}$ \\
\hline Hoje os novos não faz as festas todos os dias, faz as festas de vez em quando, não cortar cabelo não pinta \\
\hline ...quando os comunidade vamos fazer outros festa os juventude não ajudar de corre... \\
\hline $\begin{array}{l}\text {.E até agora sempre que os velhos vai discutir no pátio ou no pensão. E fazer aquela festa e nós joventude } \\
\text { vai acompanhar }\end{array}$ \\
\hline Até agora os índios novos nunca esquecer as tradição dos índios velhos \\
\hline Por isso pore enquando a gente não escutavam e nem respeitando outro não e pintar e nem cantam \\
\hline Quando meu povo gavião fazer uma festa todos homens vai para a corrida de tora \\
\hline Agora outra coisas os mais velhos contar \\
\hline mas agora tem alguma que canta a nossa cantiga.... e eu ficar preocupado. \\
\hline
\end{tabular}

\begin{tabular}{|l|}
\hline 9- SUBSTIUIÇÃO DO PRESENTE PELO GERÚNDIO \\
\hline Ainda nós tem nossa cultura e preservando e aprendendo com os mais velhos que conta a história ontesico \\
\hline E mesmo assim que nós lembrando da nossa ritual. \\
\hline Até agora nós sempre relembrando os passados, nunca nós deixamos as tradições dos kraolandios. \\
\hline A gente pintamos todos mundo no pátio cantando todos juntos \\
\hline porque nós seguindo nossa tradições antiga que os mais velho tem para repassa para os mais novo \\
\hline
\end{tabular}

\begin{tabular}{|l|}
\hline 10- SUBSTITUIÇÃO DO PRESENTE PELO PRETÉRITO \\
\hline Mais agora nesses dia nesses anos de 2006 já ta quais índios não lembrou os costumes \\
\hline $\begin{array}{l}\text { Agora os jovens já não usava aquela tradição que os velhos usavam premeiramente na cultura, mas } \\
\text { realmente a cultura continuava mesma em passado }\end{array}$ \\
\hline $\begin{array}{l}\text { Mas hoje sempre os homens juntamos no pátio conbinavam a fazer a festa mais os jovens não escutavam a } \\
\text { comunidade o que as comunidade estão fazendo }\end{array}$ \\
\hline
\end{tabular}

\begin{tabular}{|l|}
\hline 11- USO DE MARCADORES VERBAIS PARA INICIAR UM TÓPICO \\
\hline Mas eu penso no futuro eu não vou deixar meu povo perder a sua tradição \\
\hline $\begin{array}{l}\text { Eu acho que no futuro filho não vai pegar esse tradição que nosso biavô deixou para a gente.porque } \\
\text { ninguem vai querer cortar cabelo e pintar o corpo com jenipapo e urucu. Eu estou pensando assim }\end{array}$ \\
\hline $\begin{array}{l}\text { E eu penso assim, eu acho criança que vem em depois, vai peder a nossa cultura. Porque já estavam usando } \\
\text { a camisa e short. }\end{array}$ \\
\hline $\begin{array}{l}\text { Eu vou fazer a redação sobre futuro, no meu pensamento que eu penso no futuro, como eu estou } \\
\text { estudando de português e matemática, ciência, geografia, e quando eu aprender de todos matérias que eu } \\
\text { estudo na escola, e depois eu começo ganha um emprego para trabalhar com próprio mehi, na aldeia } \\
\text { cachoeira e para defende meu povo.Só isso que eu estou pensando no meu pensamento de futuro. }\end{array}$ \\
\hline
\end{tabular}

